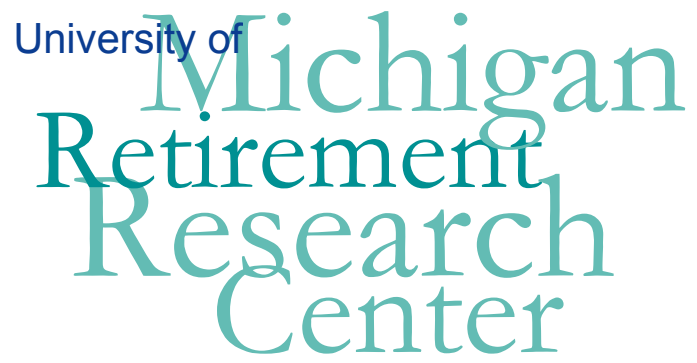

Working Paper

WP 2004-077

Characteristics of and Determinants of the Density of Contributions in a Private Social Security System

Alberto Arenas de Mesa, Jere Behrman, and David Bravo

\begin{tabular}{|l|l|l|l|l|l}
\hline$M$ & $R$ & Project \#: UM03-04 \\
\hline R & $C$ &
\end{tabular} 


\title{
Characteristics of and determinants of the density of contributions in a Private Social Security System
}

\author{
Alberto Arenas de Mesa \\ Dirección de Presupuestos, Ministerio de Hacienda, Chile. \\ Jere Behrman \\ Department of Economics, University of Pennsylvania. \\ David Bravo \\ Departamento de Economía, Universidad de Chile.
}

February 2004

\author{
Michigan Retirement Research Center \\ University of Michigan \\ P.O. Box 1248 \\ Ann Arbor, MI 48104
}

\section{Acknowledgements}

This work was supported by a grant from the Social Security Administration through the Michigan Retirement Research Center (Grant \# 10-P96362-5). The opinions and conclusions are solely those of the authors and should not be considered as representing the opinions or policy of the Social Security Administration or any agency of the Federal Government.

\section{Regents of the University of Michigan}

David A. Brandon, Ann Arbor; Laurence B. Deitch, Bingham Farms; Olivia P. Maynard, Goodrich; Rebecca McGowan, Ann Arbor; Andrea Fischer Newman, Ann Arbor; Andrew C. Richner, Grosse Pointe Park; S. Martin Taylor, Gross Pointe Farms; Katherine E. White, Ann Arbor; Mary Sue Coleman, ex officio 


\title{
Characteristics of and determinants of the density of contributions in a Private Social Security System
}

\author{
Alberto Arenas de Mesa \\ Jere Behrman \\ David Bravo
}

\begin{abstract}
This paper investigates previously unresearched issues pertaining to the wellknown Chilean innovations in Social Security. Previous empirical studies of the Chilean system used aggregate and macro data, without attention to individual heterogeneity. This study uses new household survey data, linked with Social Security records for over 20 years, to analyze selected reform issues related to social security coverage and the density and continuity of contributions to the social security system. The results lead to a better understanding of the participation determinants and the distributional aspects of the Chilean system, lay the groundwork for policy changes, and illuminate implications of the system reforms for other countries.
\end{abstract}




\section{Introduction}

This paper investigates some previously unresearched issues pertaining to the wellknown Chilean innovations in pensions and Social Security. Though some aspects of the Chilean experience have been studied extensively, these studies to date have been limited to the analysis of aggregate and macro data, without focusing on individual heterogeneity among agents affected by the system. This study uses household survey data to analyze social security coverage and the density and continuity of contributions to the Social Security system. The results lead to a better understanding of the Chilean system, laying the groundwork for policy changes, and illuminating some important implications of the system for other countries throughout the world, including the United States, which are considering reforming their Social Security systems in ways that may be parallel to certain important elements of the Chilean system.

Pension systems often are based on compulsory contributions that certain groups such as salaried workers make with the objectives of assuring their post-retirement income needs and providing coverage in the event of unforeseen circumstances that may hinder their earnings. Experience clearly indicates that, independently of the specific organization of the pension system, to protect those in the bottom of the income and wealth distributions, it is necessary to guarantee a basic minimum coverage, an aspect of social security systems that has been especially emphasized in the analysis of social security systems in Latin America in general (Mesa-Lago, 1985) and in Chile in particular (Arellano, 1985). However, beyond those basic guarantees, there are important questions about participation in voluntary systems that may substantially affect the distributional implications of the system.

Social Security systems (especially their pension components) were subject to structural reforms in Latin America in the 1990 's. Different social security schemes have been implemented in the region, with one common denominator, the introduction of individual contributions into individual pension accounts (see e.g. Mesa-Lago, 1994; 1996; and 1998; and Bonilla and Conte-Grand, 1998). Thus, it is particularly relevant to study the impact that these profound reforms have had on the coverage of the pension systems.

Within this context, the analysis of the Chilean case is particularly interesting. As is well known, Chile pioneered Social Security and pension reforms in a number of dimensions. The Chilean Individual Pension System is compulsory for salaried workers while it is optional for the self-employed. When it was instituted existing workers had to choose whether to remain in the old pay-as-you-go system or switch to the new system; however, new workers entered the new system directly. Workers affiliate to one of the private pension funds (Administradoras de Fondos de Pensiones, AFP) where they have an individual pension account. Wageworkers are mandated to contribute $10 \%$ of their monthly earnings plus an additional contribution to cover administrative costs and disability and survivor insurance. Individual funds are invested by the AFP's in a portfolio of previously authorized assets. Upon retirement, individuals use their accumulated funds to calculate the pension amount according to different schemes. Affiliates with a minimum of 20 years of contributions are entitled to receive a pension amount no less than the minimum pension set by the government.

Chile initiated its pension system reform in 1981, and therefore possesses over a decade of experience more with these reforms than do other Latin American 
countries - and of course a much stronger empirical basis for investigating the impact of these reforms than countries such as the United States that are currently considering implementing some reforms akin to those introduced two decades ago in Chile. For this reason, increasing our understanding of the Chilean system is valuable not only because it may have important implications for modifying the Chilean system, but also because it may be informative about longer-run implications of such a system for other countries.

In addition, the topic of this paper is further justified by the worrying fact that, while in 1965 over $70 \%$ of the population was covered, by 1999 coverage had fallen to less than 60\% (Arellano, 1985 and Arenas de Mesa, 2000). Furthermore, since 1981, substantial changes have also occurred in policies that have transformed the labor market, which should be considered in parallel with the Social Security system. Notwithstanding the importance of the changes in the coverage of the social security system on, for example, the social conditions of the pension holders, as well as on fiscal expenditure, these coverage changes have not been investigated sufficiently despite the considerable attention given both in Chile and abroad to the innovations in the Chilean system.

This paper reviews the issue of coverage in the new Chilean pension system. Section II provides a general overview of the pension system reform in Chile. Section III characterizes the population covered by the pension system in Chile using household surveys. Section IV characterizes and analyzes the determinants of the density of social security contributions and its dynamics. Finally, section $\mathrm{V}$ presents conclusions and policy implications. 


\section{Pension system reforms and the case of Chile}

A major objective of all the pension reforms that have swept across Latin America over the last decade has been to solve or to avoid fundamental financial imbalances. Replacing the conventional public pay-as-you-go defined benefit system (PAYG-DB) with private fully funded defined contribution schemes (FF-DC) appeared as a radical yet definite solution to actuarial disequilibria that otherwise would have required an unbearable increase in contribution rates, a reduction in benefits, or a growing drain on scarce public resources.

After the seminal experience of Chile, that substituted a public PAYG-DB system formed by a myriad of pension funds with a unified FF-DC pension system based on individual capital accounts and private administration in the early 1980s, seven other countries in Latin American have followed suit. During the 1990's Peru, Colombia, Argentina, Uruguay, Mexico, Bolivia and El Salvador have carried out reforms that have adopted FF-DC either as the core or as a fundamental pillar of new pension systems.

By funding future benefits through accumulated contributions, the authorities that advocated the move towards FF-DC schemes expected to provide a permanent solution to the periodic financial crises that plagued social security systems in the past. Such reforms also implied withdrawing from the agenda of politicians the possibility of granting disproportionate benefits to retirees at the expense of younger generations of workers.

Pension reforms were expected to have a major beneficial impact on public finances in the long run, but transition to the new regimes was a different story. Since contributions under the new system would no longer be available to fund pension payments to retirees of the PAYG system, the government would have to fund them from treasury funds, thus generating a substantial financial gap over a number of years. A fast transition from PAYG-DB to FF-DC systems would also require some recognition of accrued pension rights to those workers that moved into the new system after contributing to the old one. Pension reforms thus involved acknowledging the implicit liabilities accrued by the government both to retired and active workers. This feature of transition was recognized by international financial institutions like the World Bank and the Inter-American Development Bank that offered support to smooth the financial gap.

In addition, most of the reforms are not entirely pure in the sense of transforming a purely public PAYG-DB into a completely private FF-DC system. Due to either political compromise or to the need to keep some redistributive component, many of these reforms have retained some public responsibilities either in the form of a guaranteed minimum benefit, a basic pension funded under a traditional PAYG scheme or supplementary benefits.

The fiscal response to pension reforms is indeed a key factor in determining their success because they supplement the effect of such reforms on private savings. While the introduction of a FF-DC system will undoubtedly increase private savings (except under extreme Ricardian equivalence and perfect financial markets), national net savings will only increase as long as the reform does not prompt an equivalent reduction in public savings. Public savings, in turn, will be affected by and react to the pension reform itself. 
Chile may provide a telling example of the fiscal complexities and the social security coverage associated with pension reforms. Chile, as noted, was the first country in the world that completely substituted the old public PAYG-DB scheme with a new private FF-DC individual pension system. The scope, depth and speed of the Chilean reform has attracted worldwide attention, and is having significant influence in Latin America and other countries (see the cases of Latin American countries in MesaLago, 1996a; the United States in Diamond, 1996, and Feldstein, 1996; and Eastern European countries in Holzmann 1994).

But despite its radical nature, the Chilean reform steered far from completely eliminating the public sector from the pension system. The public sector retained a substantial role not only as regulator and with ultimate responsiblity for the functioning of the system, but also kept responsibility for: (a) paying the pensions of the old system; (b) honoring the accrued pension rights of workers that moved to the new system after contributing to the old through the payment of "recognition bonds" at retirement; (c) managing a largely unfunded DB system for the armed forces and the police; (d) guaranteeing a minimum benefit under the new system for workers that entered at least 20 years of contributions, and (e) providing a minimal welfare pension to the extremely poor elderly not eligible for the minimum benefit. Of these responsibilities, only the first two are temporary in nature but all of them draw on public funds.

The Chilean pension reform provides an interesting example to study the process of switching from a PAYG to a FF pension system. During the transition between social security systems, careful consideration should be given to the social security coverage of the pension reform because public expenditure projections on minimum pensions crucially depend on the assumption of the density of contributions, that is, the percentage of the working-life period the worker contributes to the pension system. Higher densities of contributions imply higher capital accumulation and higher benefits and, consequently, lower fiscal outlays on minimum pensions.

\section{The Chilean reform}

Chile pioneered the development of social security in Latin America, establishing its first national social insurance fund in 1924. The public pension system that evolved thereafter was fragmented and stratified, only moderately progressive and generated a growing fiscal burden. Governments of diverse political creeds unsuccessfully tried to reform this system but their attempts were blocked by powerful interest groups (Arellano 1985; Mesa-Lago 1994).

By the end of the 1970's, the pension system was diagnosed as bankrupt and the military government committed itself to carry out major reforms. A first wave of reforms rationalized the PAYG system by increasing the retirement age, raising contribution rates and eliminating the most abusive special schemes. But this proved only to set the basis for a more radical reform.

A private FF pension system was implemented in 1980 and began operating in May 1981 to replace the public PAYG scheme. The new Chilean system is compulsory for salaried workers but optional for the self-employed. When it was instituted, existing workers had to choose whether to remain in the old PAYGO system (unified in the Instituto de Normalización Previsional, INP) or change to the new system, with credit given for money paid into the old system in the form of a transferable Recognition 
Bond (RB), a financial instrument redeemed by the state to the insured at the moment of retirement and added to the fund to purchase the retirement annuity. ${ }^{1}$ It has been estimated that, during the transitional period (approximately 30 years), the RB will account for between $50 \%$ and $70 \%$ of the total capital accumulated by the insured (Arellano 1985; Arenas de Mesa and Marcel 1993). New formal sector workers were compulsorily enrolled in the new system.

The new system is a defined-contribution scheme based on a private mandatory savings/pension plan. Workers must contribute $10 \%$ of their monthly earnings during their working life to an individual account managed by a private pension fund administrator (AFP). AFP's charge fees to cover administrative costs and in addition, workers pay a premium for commercial insurance that covers survival and disability benefits. Pensions are funded by the worker's individual capitalized fund at the time of retirement, which may then be used to purchase an annuity from insurance companies. Pensions thus depend on the accumulated contributions of the affiliate over his/her working life, the yield obtained by the AFP from investing this fund in the financial markets, life expectancy factors by gender, and the number, age and life expectancy of dependants.

All pension system variables (pension funds, yields, benefits) are measured in "unidades de fomento" (UF), an accounting unit indexed to inflation. Thus, pensions are automatically inflation-adjusted, therefore solving a long-standing and serious problem of Chilean social insurance. Males can retire at the age of 65 and females at 60 . Unlike the previous system, where the management was in the hands of the public sector, the new system is managed by specialized private corporations (AFP's) dedicated exclusively to that role. However, the new private pension system is strictly regulated by the government through a Superintendence $\underline{\underline{\underline{E}}}$ julatory Authority). Moreover, the state provides numerous guarantees, $\mathrm{i} \equiv$ ding a minimum pension for all people insured who have accumulated 20 or more years of contributions throughout his/her working-life. Unlike regular pensions, however, the minimum pension is not indexed against inflation but is instead periodically adjusted by the government.

Between 1981-2003, the accumulated pension funds increased five-fold totaling more than U.S. $\$ 30$ billion or approximately $40 \%$ of GDP in 2003 . The real annual rate of return of the pension funds has averaged $11 \%$ in the $1981-2003$ period. The main exceptions were in 1995 and 1998 when the real rate of return of the pension funds fell to $-2.5 \%$ and $-1.1 \%$ respectively. However, with similarly favorable conditions as in the 1981-2003 period, the funds are expected to reach $100 \%$ of the Chilean GDP by the year 2030. Thus, the new pension system has become a key feature of the Chilean economy and it has had a major economic impact on the development and growth of financial markets.

Much literature has appeared on the new Chilean pensions system, which is understandable given its novelty (see, e.g., Cheyre, 1988; Iglesias and Acuña, 1991; Baeza and Margozzini, 1995 and SAFP, 1998). Diamond (1994), Diamond and Valdés-Prieto (1994), Arenas de Mesa (1997) and Mesa-Lago and Arenas de Mesa (1998), for example, have evaluated some implementational and operational aspects of the new Chilean pension system. However, a common characteristic of these

1 The RB is calculated using a formula based on three variables: (i) years of contributions to the public system; (ii) earnings; and (iii) annuity factors (Arenas de Mesa and Marcel 1993). 
studies, and in general of all the literature on the Chilean pension reform, is the use of aggregate and macro-economic information. In fact, the implications of the pension system reform on aspects such as private savings are usually deduced from simple aggregate correlations of macro-economic indicators (even though the period has had a significant number of other reforms) or from simulations carried out on general equilibrium models (the pioneering application in this respect was Arrau, 1991). Even when specific aspects such as the minimum basic pension have been analyzed, the analysis has been undertaken by projecting situations for representative individuals, without actually having significant empirical information and without considering individual heterogeneities that are critical for questions of coverage (see, e.g., Wagner, 1991, and Zurita, 1994). Another line of research has placed more emphasis on the fiscal aspects of the reform (see, e.g. Ortúzar, 1988; Marcel and Arenas de Mesa, 1992; Arenas de Mesa, 1999). Arenas de Mesa and Marcel (1999), for instance, have updated previous estimates on the public finance costs associated with the transition (from a pay-as-you-go to the private system) and with the guarantee of providing minimum basic pensions. But the basic question of coverage has not been considered very much in the analysis of the Chilean pension system to date. 


\section{Characterization of the population covered by the pension system in Chile}

In this section, we characterize the population covered by the pension system in Chile working first from official figures and then using information from household surveys that distinguish between contributors and non-contributors.

\subsection{General Trends 1975-2000}

Table 1 reports the number of people contributing to the pension system in Chile since 1975 as a percentage of total employment and of the labor force ${ }^{2}$. Note the large proportion of people who moved from the old pay-as-you-go system (INP) to the new system (AFP): in 1982-1983, 7 out of 10 contributors were in the AFP system. Moreover, because all new workers have to enter the new system, the AFP's are increasingly dominant. By $2000,93 \%$ of contributors were integrated into the AFP system.

Table 1

Pension System Coverage in Chile: 1975-2000

\begin{tabular}{|c|c|c|c|c|c|c|}
\hline \multirow[t]{2}{*}{ Year } & \multicolumn{3}{|c|}{$\begin{array}{c}\text { Coverage Index } 1 \\
\text { (Contributors/Employment) }\end{array}$} & \multicolumn{3}{|c|}{$\begin{array}{c}\text { Coverage Index } 2 \\
\text { (Contributors/Labor Force) }\end{array}$} \\
\hline & AFP & INP & Total & AFP & INP & Total \\
\hline 1975 & ----- & $71.2 \%$ & $71.2 \%$ & ----- & $61.9 \%$ & $61.9 \%$ \\
\hline 1976 & ----- & $65.7 \%$ & $65.7 \%$ & ----- & $57.3 \%$ & $57.3 \%$ \\
\hline 1977 & ----- & $62.2 \%$ & $62.2 \%$ & ----- & $54.8 \%$ & $54.8 \%$ \\
\hline 1978 & ----- & $56.6 \%$ & $56.6 \%$ & ----- & $48.5 \%$ & $48.5 \%$ \\
\hline 1979 & ----- & $56.2 \%$ & $56.2 \%$ & ----- & $48.5 \%$ & $48.5 \%$ \\
\hline 1980 & ----- & $53.3 \%$ & $53.3 \%$ & ----- & $47.8 \%$ & $47.8 \%$ \\
\hline 1981 & n.d. & $18.4 \%$ & n.d. & n.d. & $16.3 \%$ & n.d. \\
\hline 1982 & $36.0 \%$ & $16.6 \%$ & $52.6 \%$ & $29.0 \%$ & $13.4 \%$ & $42.3 \%$ \\
\hline 1983 & $38.2 \%$ & $14.9 \%$ & $53.1 \%$ & $33.5 \%$ & $13.0 \%$ & $46.6 \%$ \\
\hline 1984 & $40.6 \%$ & $13.7 \%$ & $54.3 \%$ & $35.0 \%$ & $11.8 \%$ & $46.8 \%$ \\
\hline 1985 & $44.0 \%$ & $12.8 \%$ & $56.9 \%$ & $38.8 \%$ & $11.3 \%$ & $50.1 \%$ \\
\hline 1986 & $45.9 \%$ & $11.6 \%$ & $57.5 \%$ & $41.1 \%$ & $10.4 \%$ & $51.6 \%$ \\
\hline 1987 & $50.6 \%$ & $11.0 \%$ & $61.6 \%$ & $45.7 \%$ & $10.0 \%$ & $55.7 \%$ \\
\hline 1988 & $50.6 \%$ & $9.8 \%$ & $60.4 \%$ & $46.6 \%$ & $9.0 \%$ & $55.6 \%$ \\
\hline 1989 & $50.8 \%$ & $8.7 \%$ & $59.5 \%$ & $47.2 \%$ & $8.1 \%$ & $55.3 \%$ \\
\hline 1990 & $50.6 \%$ & $8.1 \%$ & $58.7 \%$ & $46.8 \%$ & $7.5 \%$ & $54.4 \%$ \\
\hline 1991 & $53.7 \%$ & $7.6 \%$ & $61.3 \%$ & $49.9 \%$ & $7.0 \%$ & $56.9 \%$ \\
\hline 1992 & $55.3 \%$ & $6.9 \%$ & $62.2 \%$ & $51.8 \%$ & $6.5 \%$ & $58.3 \%$ \\
\hline 1993 & $54.6 \%$ & $6.0 \%$ & $60.7 \%$ & $51.1 \%$ & $5.7 \%$ & $56.8 \%$ \\
\hline 1994 & $56.2 \%$ & $5.5 \%$ & $61.7 \%$ & $51.8 \%$ & $5.0 \%$ & $56.9 \%$ \\
\hline 1995 & $57.2 \%$ & $5.5 \%$ & $62.7 \%$ & $53.5 \%$ & $5.1 \%$ & $58.6 \%$ \\
\hline 1996 & $58.9 \%$ & $4.9 \%$ & $63.8 \%$ & $55.7 \%$ & $4.6 \%$ & $60.4 \%$ \\
\hline 1997 & $61.3 \%$ & $4.4 \%$ & $65.6 \%$ & $58.0 \%$ & $4.1 \%$ & $62.1 \%$ \\
\hline 1998 & $58.0 \%$ & $4.2 \%$ & $62.2 \%$ & $53.8 \%$ & $3.9 \%$ & $57.7 \%$ \\
\hline 1999 & $60.4 \%$ & $4.2 \%$ & $64.6 \%$ & $55.0 \%$ & $3.9 \%$ & $58.9 \%$ \\
\hline 2000 & $59.4 \%$ & $4.2 \%$ & $63.6 \%$ & $54.5 \%$ & $3.9 \%$ & $58.4 \%$ \\
\hline
\end{tabular}

Source: Arenas de Mesa (2000) y Arellano (1985).

\footnotetext{
2 Table 1 uses figures of contributors from official social security sources (INP in the case of the old system and Superintendencia de AFP for the new pension system) and labor force statistics coming from the Instituto Nacional de Estadísticas (INE).
} 
In 1975 , the coverage index 1 was over $70 \%$ (and according to Arellano, 1985, this was also the figure between 1965 and 1975). It then dropped continuously down to around $53 \%$ at the beginning of the new system in 1981. Later, coverage picked up to $62 \%$ in 1987 and reached $64-65 \%$ in the last couple of years covered in the table. Therefore, when compared with the 1975 figures, 20 years of the new system have not actually led to an increase in coverage.

This lack of substantial change in coverage generally has not been recognized because coverage index 3 shown in table 2 usually has been reported: that is, the number of affiliates (instead of contributors) to the new system as a proportion of the total labor force. Contrary to what was shown in Table 1, by this index over $100 \%$ of the labor force would be currently covered in the AFP system.

Table 2

Coverage in the AFP System 1981-2000 using affiliation

\begin{tabular}{|c|c|c|c|}
\hline Year & $\begin{array}{c}\text { Affiliates } \\
\text { (a) }\end{array}$ & $\begin{array}{l}\text { Labor Force } \\
\text { (b) }\end{array}$ & $\begin{array}{l}\text { Coverage } \\
\text { Index } 3 \\
\text { (c) }=(a) /(b)\end{array}$ \\
\hline 1981 & 1.400 .000 & 3.687 .900 & $38.0 \%$ \\
\hline 1982 & 1.440 .000 & 3.660 .700 & $39.3 \%$ \\
\hline 1983 & 1.620 .000 & 3.667 .700 & $44.2 \%$ \\
\hline 1984 & 1.930 .353 & 3.890 .700 & $49.6 \%$ \\
\hline 1985 & 2.283 .830 & 4.018 .700 & $56.8 \%$ \\
\hline 1986 & 2.591 .484 & 4.312 .010 & $60.1 \%$ \\
\hline 1987 & 2.890 .680 & 4.425 .330 & $65.3 \%$ \\
\hline 1988 & 3.183 .002 & 4.656 .280 & $68.4 \%$ \\
\hline 1989 & 3.470 .845 & 4.805 .290 & $72.2 \%$ \\
\hline 1990 & 3.739 .542 & 4.888 .590 & $76.5 \%$ \\
\hline 1991 & 4.109 .184 & 4.983 .890 & $82.4 \%$ \\
\hline 1992 & 4.434 .795 & 5.199 .800 & $85.3 \%$ \\
\hline 1993 & 4.708 .840 & 5.458 .990 & $86.3 \%$ \\
\hline 1994 & 5.014 .444 & 5.553 .830 & $90.3 \%$ \\
\hline 1995 & 5.320 .913 & 5.538 .240 & $96.1 \%$ \\
\hline 1996 & 5.571 .482 & 5.600 .670 & $99.5 \%$ \\
\hline 1997 & 5.780 .400 & 5.683 .820 & $101.7 \%$ \\
\hline 1998 & 5.966 .143 & 5.851 .510 & $102.0 \%$ \\
\hline 1999 & 6.105 .731 & 5.933 .560 & $102.9 \%$ \\
\hline 2000 & 6.280 .191 & 5.870 .880 & $107.0 \%$ \\
\hline
\end{tabular}

However, coverage index 3 is inadequate because, in the new pension system, the affiliation condition is obtained automatically when someone works in the formal sector and makes a contribution to the pension system. Even if a person has only contributed one month in a period of 20 years, such a person will nevertheless appear as affiliated in table 2 . Therefore, affiliation is a very misleading index of being covered in the new pension system.

Coverage indexes 1 and 2 are also open to criticism because they give no information on the density and continuity of contributions. Even when only considering those who are actively contributing to the pension system and who are employed in some point in time (covered in both indexes), accumulated savings may be insufficient. Despite these limitations, in this section we will continue working with 
indexes type 1 and 2 that only distinguish contributors from non-contributors; in section 4 of the paper we will use information from a new household survey to characterize the density of contributions.

Some publications also have interpreted available statistics as showing higher pension coverage for women relative to men in the AFP system, either using index 1 or 2. In fact, when index 2 is used, coverage increased in the 1986-2000 period from $37 \%$ to $51 \%$ for women and from $34 \%$ to $45 \%$ for men. Barrientos (1998) concludes that this feature contrasts with the experience of developed countries where a coverage gender gap against women can be found; in fact, he goes further and predicts that a wave of reforms in pension systems along the lines of the Chilean system would contribute to a reduction in the gender gap in coverage.

The assertion that coverage for women is higher will be tested in section 3.2 using household survey data. However, even if we could confirm that coverage is higher for women (which will not be the case), it is not possible to attribute the causality to the new pension system. To begin with, we don't have any information on gender gaps in pension coverage before 1981 to be able to compare the current situation with the old system. Secondly, the differential in gender gap coverage between Chile and other developed countries cannot easily be attributed to the new pension system when other important factors are not controlled (among them, different rules on the mandatory character of contributions and large differences in the labor force participation of women). At the same time, there is the usual selection issue when we consider female labor force participation. Therefore, in section 4 we will investigate the gender gap in coverage as related to density of contributions.

\subsection{Characterizing pension coverage using household surveys: 1992-2000}

In this section we use individual information from the National Socio-economic Characterization Surveys (CASEN) for the years 1990, 1992, 1994, 1996, 1998 and 2000 to contribute to the debate on pension coverage. The CASEN survey is significant because it provides a body of data on households that is representative on a regional as well as on a national level. The surveys are carried out in November of each year and provide cross-sectional information on approximately 130 thousand people a year. This survey is carried out by the Survey Unit of the Economics Department of the University of Chile on behalf of the Chilean Ministry of Planning (MIDEPLAN).

The surveys between 1990 and 1998 included the question: "Are you affiliated to any pension system?" moreover, the surveys between 1992 and 2000 included another question: "Do you make contributions into any pension system?" The series generated on contributors is homogenous over time. However, the questions on affiliation between 1990 and 1992 were not asked to the entire working-age population. The question on those affiliated to pension systems was only put to people actively working in 1990 while in 1992 the question was only put to those not working (inactive and unemployed). From 1994, everyone was asked the same question, but it was not repeated until the year 2000 . These changes limit the use of the information on those affiliated to pension systems in the econometric analysis before 1994. However, for the tables included in this section, the total of those affiliated was estimated using imputations for the missing information based on the evidence from the nearest years. 
Table 3 provides some pertinent indicators taken from the 1990 to 2000 CASEN surveys. As may be seen, the unemployment rate dropped in the 90 's in the period under analysis but increased in 1998 and 2000. Through 1998 female labor force participation rate increased, though it fell a little in 2000. Likewise, and in contrast to the claim by some observers of the labor market of a deteriorating trend in the quality and stability of employment, the percentage of workers with a contract actually increased significantly through 1994 and though it subsequently declined a little, it remained above the 1992 value. Also the proportion of employees who work as wage workers has grown slightly over more of the period, with a slight decline in 2000. Therefore, the traditional informal employment measures have dropped in the period.

The coverage indicators that use pension system membership rates relative to the size of the labor force (affiliates/labor force) are less than $100 \%$ on average, in contrast to Table 2. However, this indicator is higher for women and indeed exceeds $100 \%$ for $1994-8$. Thus the patterns are similar to those in Table 2, though at a somewhat lower levels (which may reflect underreporting with self-reporting).

Table 3

Indicators from CASEN Household Surveys 1990-2000

\begin{tabular}{|c|c|c|c|c|c|c|}
\hline Indicator & 1990 & 1992 & 1994 & 1996 & 1998 & 2000 \\
\hline Unemployment Rate & $8.3 \%$ & $5.5 \%$ & $6.7 \%$ & $5.7 \%$ & $9.9 \%$ & $10.2 \%$ \\
\hline Labor Force Participation & $52.0 \%$ & $54.0 \%$ & $54.5 \%$ & $54.7 \%$ & $55.9 \%$ & $51.6 \%$ \\
\hline Female Labor Force Participation & $32.4 \%$ & $34.1 \%$ & $35.3 \%$ & $36.3 \%$ & $38.8 \%$ & $36.6 \%$ \\
\hline$\%$ of employed with contract & $68.7 \%$ & $71.6 \%$ & $79.5 \%$ & $76.5 \%$ & $75.2 \%$ & $75.2 \%$ \\
\hline$\%$ of employed who are wage workers & $66.6 \%$ & $67.2 \%$ & $67.1 \%$ & $68.6 \%$ & $68.7 \%$ & $68.1 \%$ \\
\hline Contributors/Employed & na & $60.7 \%$ & $64.6 \%$ & $64.1 \%$ & $63.4 \%$ & $62.1 \%$ \\
\hline -Men & na & $61.2 \%$ & $65.1 \%$ & $64.5 \%$ & $64.0 \%$ & $63.0 \%$ \\
\hline -Women & na & $59.8 \%$ & $63.7 \%$ & $63.3 \%$ & $62.2 \%$ & $60.3 \%$ \\
\hline Contributors/Labor Force & na & $57.4 \%$ & $60.3 \%$ & $60.4 \%$ & $57.1 \%$ & $55.7 \%$ \\
\hline- Men & na & $58.5 \%$ & $61.4 \%$ & $61.3 \%$ & $58.2 \%$ & $57.1 \%$ \\
\hline -Women & na & $55.3 \%$ & $58.2 \%$ & $58.7 \%$ & $55.2 \%$ & $53.4 \%$ \\
\hline Contributors/Population 15 and older & na & $31.0 \%$ & $32.9 \%$ & $33.1 \%$ & $31.9 \%$ & $28.8 \%$ \\
\hline -Men & na & $44.4 \%$ & $46.4 \%$ & $45.8 \%$ & $43.4 \%$ & $38.7 \%$ \\
\hline -Women & na & $18.9 \%$ & $20.6 \%$ & $21.3 \%$ & $21.4 \%$ & $19.5 \%$ \\
\hline Affiliates/Labor Force & $81.6 \%$ & $86.1 \%$ & $91.0 \%$ & $95.0 \%$ & $95.1 \%$ & na \\
\hline -Men & $74.9 \%$ & $80.0 \%$ & $82.8 \%$ & $86.4 \%$ & $87.2 \%$ & na \\
\hline -Women & $96.7 \%$ & $98.5 \%$ & $107.0 \%$ & $111.3 \%$ & $109.1 \%$ & na \\
\hline Affiliates/Population 15 and older & $42.4 \%$ & $46.5 \%$ & $49.6 \%$ & $52.0 \%$ & $53.2 \%$ & na \\
\hline- Men & $55.2 \%$ & $60.7 \%$ & $62.5 \%$ & $64.5 \%$ & $65.1 \%$ & na \\
\hline -Women & $31.3 \%$ & $33.6 \%$ & $37.8 \%$ & $40.4 \%$ & $42.3 \%$ & na \\
\hline
\end{tabular}

Source: Computations using files from CASEN Household Surveys.

na: not available

We think that the indicator of affiliates relative to the working age population (taken as the population of 15 years of age and over) is more useful when using data on affiliations. Using this data, it is clear that the higher affiliation rate previously observed for women was predominantly due to their low participation level. This indicator shows that over half the working-age population is affiliated to the pension system, with significantly higher rates for men than for women.

As regards the indicators associated with contributors, a similar picture to Table 1 appears, with an increase in coverage rates between 1992 and 1994-1996. However, 
in contrast to the evidence from other studies, in all these cases the coverage indicators are slightly higher for men than for women. To reconcile this pattern with the opposite one noted above, that the figures from Table 3 include the contributors from the old pension system (INP) as well as those in the Defense force and Police pension system (these latter are predominantly male) needs to be taken into account. The figures for AFP affiliates show similar coverage rates for men and women.

The advantages of having household information on an individual level, however, are not fully exploited in Table 3 . Table 4 shows coverage index 1 (contributors over employment) for a group of individual characteristics, which allows better understanding as to the factors that are correlated with a greater or lower coverage:

Age groups: Coverage is highest for the 25 and 29 age group, with a peak at $72.0 \%$ in 1996 for this age group. Coverage is particularly low for workers of schoolgoing age (15 to 19 years of age) and for adults 60 or over (a range that includes male and female retirement ages). The lower coverage rate observed in those aged 30 and over relative to those in their 20 s probably is related to the lower educational levels of older cohorts relative to the younger groups (Bravo and Contreras (2001); Bravo and Marinovic (1997)).

Schooling attainment: The above suggestion about the age-schooling-coverage pattern is plausible in that a positive relationship is observed between schooling levels and pension coverage rates. Only 40-45 out of every 100 low or unskilled workers make social security contributions. This contrasts sharply with the 70 to $75 \%$ coverage for workers with a full secondary education (note that workers with partial secondary education have coverage rates some 10 to 15 points lower). These rates exceed $75 \%$ for workers with unfinished higher education (university) or with higher technical training, and hover around $85 \%$ for workers with completed higher education (university). Given the increasing schooling attainment of recent schoolage cohorts in Chile, the workforce's average schooling will increase over the next 10 years; therefore, pension coverage is expected to increase simply for this reason.

Geographical patterns: There is a clear pattern of a $50 \%$ higher coverage in urban areas over rural zones. This is consistent with the fact that low coverage rates are observed in regions IV, VII, IX and X, all with above average rural populations. In contrast, regions XII, II and the Metropolitan, have coverage rates above the national average. This pattern is stable over the period of analysis. 
Table 4

Coverage Index 1 (Contributors/Employment)

\begin{tabular}{|c|c|c|c|c|c|}
\hline \multirow[t]{2}{*}{ Variables } & \multicolumn{5}{|c|}{ CASEN Surveys } \\
\hline & 1992 & 1994 & 1996 & 1998 & 2000 \\
\hline 1. Total & $60.7 \%$ & $64.6 \%$ & $64.1 \%$ & $63.4 \%$ & $62.2 \%$ \\
\hline \multicolumn{6}{|l|}{ 2. Sex: } \\
\hline -Men & $61.2 \%$ & $65.1 \%$ & $64.5 \%$ & $64.0 \%$ & $63.2 \%$ \\
\hline -Women & $59.8 \%$ & $63.7 \%$ & $63.3 \%$ & $62.2 \%$ & $60.4 \%$ \\
\hline \multicolumn{6}{|l|}{ 3. Age: } \\
\hline$-15-19$ years & $35.5 \%$ & $41.5 \%$ & $36.5 \%$ & $34.9 \%$ & $33.6 \%$ \\
\hline$-20-24$ years & $61.5 \%$ & $66.1 \%$ & $65.1 \%$ & $63.8 \%$ & $59.5 \%$ \\
\hline$-25-29$ years & $67.6 \%$ & $71.2 \%$ & $72.0 \%$ & $70.0 \%$ & $69.1 \%$ \\
\hline$-30-39$ years & $65.1 \%$ & $68.7 \%$ & $68.8 \%$ & $67.7 \%$ & $67.4 \%$ \\
\hline$-40-49$ years & $62.5 \%$ & $65.7 \%$ & $64.7 \%$ & $64.7 \%$ & $63.5 \%$ \\
\hline$-50-59$ years & $56.3 \%$ & $61.6 \%$ & $59.9 \%$ & $61.8 \%$ & $60.8 \%$ \\
\hline-60 and older & $46.5 \%$ & $46.4 \%$ & $44.2 \%$ & $41.9 \%$ & $40.8 \%$ \\
\hline \multicolumn{6}{|l|}{ 4. Schooling: } \\
\hline -None & $39.8 \%$ & $43.5 \%$ & $39.3 \%$ & $39.2 \%$ & $37.3 \%$ \\
\hline -Primary Incomplete & $47.5 \%$ & $47.9 \%$ & $46.3 \%$ & $44.8 \%$ & $42.7 \%$ \\
\hline -Primary Complete & $53.2 \%$ & $54.5 \%$ & $53.9 \%$ & $52.2 \%$ & $53.0 \%$ \\
\hline -Secondary Incomplete & $58.4 \%$ & $60.8 \%$ & $61.3 \%$ & $58.2 \%$ & $54.9 \%$ \\
\hline -Secondary Complete & $70.1 \%$ & $73.0 \%$ & $74.2 \%$ & $71.5 \%$ & $69.9 \%$ \\
\hline -Higher Incomplete & $73.7 \%$ & $74.8 \%$ & $77.4 \%$ & $76.3 \%$ & $75.1 \%$ \\
\hline -Higher Complete & $83.0 \%$ & $87.7 \%$ & $83.8 \%$ & $85.1 \%$ & $83.3 \%$ \\
\hline \multicolumn{6}{|l|}{ 5. Zone: } \\
\hline -Urban & $64.3 \%$ & $67.7 \%$ & $67.8 \%$ & $66.6 \%$ & $65.0 \%$ \\
\hline -Rural & $43.1 \%$ & $46.9 \%$ & $41.9 \%$ & $41.5 \%$ & $43.0 \%$ \\
\hline \multicolumn{6}{|l|}{ 6. Region: } \\
\hline-1 & $69.8 \%$ & $69.5 \%$ & $66.5 \%$ & $63.5 \%$ & $60.4 \%$ \\
\hline- II & $68.1 \%$ & $68.6 \%$ & $68.4 \%$ & $70.9 \%$ & $74.2 \%$ \\
\hline - III & $68.0 \%$ & $66.1 \%$ & $68.0 \%$ & $69.4 \%$ & $68.4 \%$ \\
\hline- IV & $53.0 \%$ & $58.3 \%$ & $59.5 \%$ & $56.7 \%$ & $56.8 \%$ \\
\hline$-v$ & $62.1 \%$ & $65.5 \%$ & $65.2 \%$ & $63.1 \%$ & $60.8 \%$ \\
\hline- VI & $64.8 \%$ & $66.4 \%$ & $65.2 \%$ & $64.8 \%$ & $62.5 \%$ \\
\hline- VII & $50.6 \%$ & $54.7 \%$ & $51.5 \%$ & $54.2 \%$ & $55.0 \%$ \\
\hline- VIII & $57.1 \%$ & $66.0 \%$ & $62.7 \%$ & $62.3 \%$ & $61.0 \%$ \\
\hline$-I X$ & $49.2 \%$ & $51.3 \%$ & $45.8 \%$ & $52.4 \%$ & $49.5 \%$ \\
\hline$-x$ & $54.2 \%$ & $56.1 \%$ & $54.4 \%$ & $54.2 \%$ & $55.8 \%$ \\
\hline$-\mathbf{X I}$ & $61.5 \%$ & $59.4 \%$ & $61.2 \%$ & $60.9 \%$ & $65.3 \%$ \\
\hline$-X I I$ & $73.0 \%$ & $74.0 \%$ & $70.7 \%$ & $74.7 \%$ & $75.5 \%$ \\
\hline - Metropolitan & $63.8 \%$ & $67.8 \%$ & $69.1 \%$ & $67.1 \%$ & $65.3 \%$ \\
\hline
\end{tabular}


Table 4 (cont.)

Coverage Index 1 (Contributors/Employment)

\begin{tabular}{|c|c|c|c|c|c|}
\hline \multirow[t]{2}{*}{ Variables } & \multicolumn{5}{|c|}{ CASEN Surveys } \\
\hline & 1992 & 1994 & 1996 & 1998 & 2000 \\
\hline \multicolumn{6}{|l|}{ 7. Head of Household: } \\
\hline -Head & $63.1 \%$ & $65.9 \%$ & $66.3 \%$ & $65.2 \%$ & $64.7 \%$ \\
\hline -Non Head & $58.3 \%$ & $63.2 \%$ & $61.8 \%$ & $61.4 \%$ & $59.5 \%$ \\
\hline \multicolumn{6}{|l|}{ 8. Marriage Status: } \\
\hline -Single & $57.8 \%$ & $63.4 \%$ & $61.0 \%$ & $61.6 \%$ & $60.6 \%$ \\
\hline -Married, widow, divorced & $62.1 \%$ & $65.1 \%$ & $65.3 \%$ & $64.0 \%$ & $62.7 \%$ \\
\hline \multicolumn{6}{|l|}{ 9. Occupation: } \\
\hline -Defense and police & $79.6 \%$ & $86.1 \%$ & $95.5 \%$ & $97.7 \%$ & $97.0 \%$ \\
\hline -Managers & $50.2 \%$ & $48.9 \%$ & $52.1 \%$ & $49.9 \%$ & $41.8 \%$ \\
\hline -Professionals & $84.7 \%$ & $89.6 \%$ & $86.2 \%$ & $86.8 \%$ & $85.5 \%$ \\
\hline -Technicians/medium level profess. & $79.6 \%$ & $81.6 \%$ & $82.7 \%$ & $83.2 \%$ & $79.6 \%$ \\
\hline -White collar workers & $84.1 \%$ & $86.3 \%$ & $89.6 \%$ & $87.0 \%$ & $86.2 \%$ \\
\hline -Sales and service workers & $56.2 \%$ & $59.9 \%$ & $61.3 \%$ & $61.8 \%$ & $59.4 \%$ \\
\hline -Agricultural workers & $37.0 \%$ & $34.3 \%$ & $31.4 \%$ & $30.9 \%$ & $38.6 \%$ \\
\hline -Blue collar workers & $58.1 \%$ & $59.0 \%$ & $59.7 \%$ & $55.4 \%$ & $54.8 \%$ \\
\hline -Machine operators & $69.5 \%$ & $73.4 \%$ & $72.8 \%$ & $68.2 \%$ & $68.2 \%$ \\
\hline -Non-skilled workers & $52.7 \%$ & $56.4 \%$ & $54.0 \%$ & $52.7 \%$ & $53.2 \%$ \\
\hline \multicolumn{6}{|l|}{ 10.Economic Activity: } \\
\hline -Agriculture & $44.7 \%$ & $47.6 \%$ & $43.6 \%$ & $43.7 \%$ & $45.2 \%$ \\
\hline -Mining & $79.1 \%$ & $85.8 \%$ & $83.8 \%$ & $87.7 \%$ & $86.7 \%$ \\
\hline -Manufacturing & $69.4 \%$ & $72.6 \%$ & $74.4 \%$ & $72.6 \%$ & $70.8 \%$ \\
\hline -Electricity,gas and water & $85.1 \%$ & $83.6 \%$ & $85.4 \%$ & $85.4 \%$ & $86.5 \%$ \\
\hline -Construction & $64.7 \%$ & $63.9 \%$ & $65.3 \%$ & $60.4 \%$ & $58.1 \%$ \\
\hline -Trade & $50.4 \%$ & $54.8 \%$ & $55.6 \%$ & $55.4 \%$ & $53.4 \%$ \\
\hline -Transport and Communications & $59.8 \%$ & $65.8 \%$ & $62.3 \%$ & $62.0 \%$ & $59.1 \%$ \\
\hline -Financial Services & $79.9 \%$ & $84.8 \%$ & $82.6 \%$ & $81.2 \%$ & $78.4 \%$ \\
\hline -Services & $66.2 \%$ & $69.5 \%$ & $69.7 \%$ & $68.6 \%$ & $68.2 \%$ \\
\hline \multicolumn{6}{|l|}{ 11.Employment Category: } \\
\hline -Employer & $45.8 \%$ & $50.1 \%$ & $50.7 \%$ & $49.6 \%$ & $52.6 \%$ \\
\hline -Self-employed & $19.4 \%$ & $22.6 \%$ & $21.1 \%$ & $19.9 \%$ & $17.4 \%$ \\
\hline -Wage Worker & $76.9 \%$ & $82.4 \%$ & $79.7 \%$ & $79.2 \%$ & $78.2 \%$ \\
\hline -Domestic Service & $50.1 \%$ & $49.9 \%$ & $46.5 \%$ & $44.3 \%$ & $44.3 \%$ \\
\hline -Family worker (without wage) & $9.6 \%$ & $10.9 \%$ & $5.8 \%$ & $6.6 \%$ & $7.2 \%$ \\
\hline \multicolumn{6}{|l|}{ 12.Labor Contract: } \\
\hline -Yes & $91.9 \%$ & $93.7 \%$ & $93.7 \%$ & $94.6 \%$ & $94.0 \%$ \\
\hline$-\mathrm{No}$ & $31.3 \%$ & $26.3 \%$ & $24.6 \%$ & $21.9 \%$ & $18.9 \%$ \\
\hline \multicolumn{6}{|l|}{ 13. Firm Size: } \\
\hline$-1-9$ workers & $39.0 \%$ & $41.0 \%$ & $44.2 \%$ & $38.2 \%$ & $37.0 \%$ \\
\hline$-10-49$ workers & $77.5 \%$ & $83.3 \%$ & $81.7 \%$ & $79.7 \%$ & $78.2 \%$ \\
\hline$-50-199$ workers & $85.2 \%$ & $88.6 \%$ & $87.2 \%$ & $87.0 \%$ & $85.8 \%$ \\
\hline-200 and + workers & $89.2 \%$ & $91.9 \%$ & $92.7 \%$ & $90.4 \%$ & $90.7 \%$ \\
\hline
\end{tabular}


Table 4 (cont.)

Coverage Index 1 (Contributors/Employment)

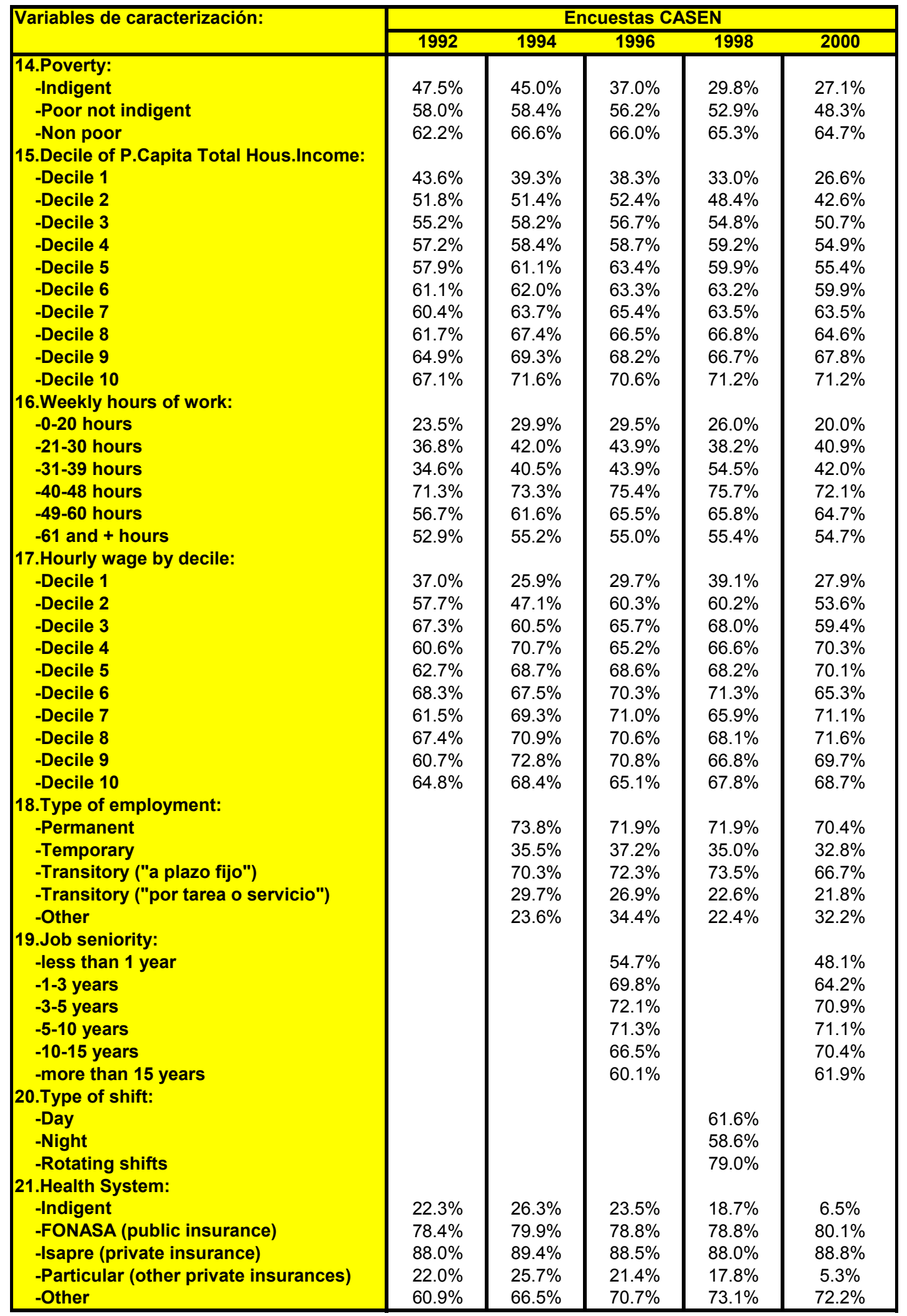

Source: computed using CASEN Household Survey Files. 
Household and marital status: Heads of households have somewhat higher coverage relative to others, though the difference is only about five percentage points. Those who have been ever married have somewhat higher coverage than those who have not, though again the difference is not very large.

Occupation and sector of economic activity: Defense force employees, professionals, technicians, midlevel professionals and white-collar workers have high coverage rates. In contrast, agricultural workers have the lowest coverage rates, with bluecollar and non-skilled workers next lowest. Among sectors of economic activity, agriculture has the lowest coverage levels (about 45\%), with trade (50-55\%) next. At the other extreme, mining, electricity, gas, water and financial services have the highest rates (all over $80 \%$ ).

Employment category: Non-remunerated family members (between 6 and 10\%) and self-employed workers (about $20 \%$ stand out at the low end of the coverage distribution. Arenas de Mesa (2000) finds that approximately 4\% of all independent workers pay into a pension fund (AFP). Even including INP covered workers, the percentage is significantly below the $20 \%$ that declare making contributions in the CASEN surveys. This contrast suggests that independent workers have alternative savings systems that they consider as pension contributions and that substitute for pension contributions or that, alternatively, the workers surveyed could be using a different time frame (e.g., they could be referring to contributions made in the preceding year in the CASEN, while Arenas de Mesa is referring to monthly data). The analysis by employment category also highlights the low coverage levels among domestic service workers and employers with rates below or approaching $50 \%$. At the other end of the distribution, wage workers have the highest coverage rates (around $80 \%$ ).

Labor contract status: Over $90 \%$ of wage workers with contracts make pension contributions, but only $20 \%$ of those without contracts. Therefore, there is correlation between these two indicators of employment formality.

Firm size: Average coverage rates increase monotonically with the number of workers in a firm, particularly with movement from below ten to more than ten workers. Coverage rates are about half as large for firms with less than ten workers (and less than 45\%) than for firms with 10-49 workers (around $80 \%$ ). In contrast, the rate for mid-sized companies with $50-199$ workers is greater than $85 \%$ and is about $90 \%$ for large companies with $200+$ workers.

Poverty, income, wage rate and hours worked distributions: Coverage is positively related to household per capita income. Moreover, over the time period covered, the dispersion of coverage with income increased. Coverage rates dropped in the lower deciles, particularly sharply for those categorized as indigenet (from $47.5 \%$ in 1992 to $27.1 \%$ in 2000 ) but also for those categorized as poor but not indigent (from $58.0 \%$ to $48.3 \%$ ). In contrast, coverage for the nonpoor increased from $62.2 \%$ in 1992 to a peak of $66.0 \%$ in 1996 and then declined slightly to $64.7 \%$ in 2000 . Similar patterns, but with less sharp differences, are observed for the wage rate distribution. The patterns are less sharp in part because the coverage rates are not, monotonic with respect to hours worked per week, but are substantially higher (over $70 \%$ ) for those who work 40-48 hours than for those who work more (which may be reflecting the selection of poorly qualified workers in this group) or (particularly) those who work less (part-time workers). In addition there is the important distinction between individual wages and household income, with coverage 
apparently lower in households who are relatively low in the per capita income distribution because they have relatively few workers.

Type of employment contract and seniority: Workers with temporary contracts, or contracts for specific tasks have very low coverage rate (less than half the coverage of workers with permanent contracts). On the other hand, workers with fixed-term contracts have surprisingly high coverage levels, as well as those who do shift work. Coverage also increases initially with seniority, though it peaks on average with only 3-5 years of seniority.

Health coverage: Only about $20 \%$ of those who declare themselves indigent for the purposes of the health system contribute to the pension system, and there is a sharply decling tendency from the peak of $26.3 \%$ in 1994 to $6.5 \%$ in 2000 . The pattern is similar for those who declare having private health plans. However, about $80 \%$ of those who declare belonging to FONASA (The National Health Fund) and over $88 \%$ of those who contribute to ISAPRE (Private Health Funds) also make pension contributions. While these rates are high, it still is possible to have a health plan and to not contribute to any pension system.

To sum up, the information presented in this section provides a broader characterization of individuals in Chile with and without pension system coverage when the definition based on making contributions is used. However, this characterization is limited because it is based on bivariate tabulations. The next section turns to multivariate analysis. 


\subsection{Regressions for the probability of making social security contributions using repeated cross-section CASEN surveys for 1992-2000}

This section considers the factors associated with making contributions to the pension system (based on the self-reporting in the household surveys) for the subsample of workers. This multivariate analysis distinguishes between two states: contributor and non-contributor. This analysis permits establishing whether the correlations detected earlier hold once the complete vector of right-side variables is considered. Probit models with hetero-skedasticity corrections have been used to estimate the probability of contributing under different specifications for this analysis. . Table 5 gives the estimates for basically the identical specification (except some of the contractual variables are not available for 1992) for the 1992, 1994, 1996, 1998 and 2000 CASEN surveys. The right-side varaiables are those that are discussed for the bivariate relations in the Section 3.2.

Gender: Once there are multivariate controls, men are more likely to make contributions than women, in contrast with the results in Barrientos (1998). In the period under analysis, men have between 5 and 9 additional points of probability of making contributions than do women. This is greater than the $1-2 \%$ gap in the bivariate estimates in Table 4. Therefore, the failure to control for other characteristics leads to higher pension coverage associations for women relative to men, but this difference is not robust fact if other characteristics are includedof men.

Age: A statistically significant concave relationship between age and the probability of making pension contributions is observed, which tends to become stronger over the period considered. Thus, for example, initially for every additional year of age, the probability of contributing increases between 1 and 2 percentage points, but this probability decreases rapidly so, at around 45 years, the correlation disappears, which is consistent with what appears in the simple tabulations of the previous section. The important point is that this correlation holds even when considering individuals with the same education and with control for the rest of the variables included in Table 5.

Schooling attainment: The positive relationship between schooling attainment and the probability of making pension contributions in the bivariate analysis tends to persist in the multivariate analysis even though this relation varies somewhat across the years. On average, a completed secondary education or a completed higher education is associated with an 0.05 higher probability of making contributions. This suggests that increases in the average schooling of the labor force will lead to, ceteris paribus, increases in pension coverage.

Geographical residence: There is a general advantage of some 4 to 5 points of probability when living in an urban zone that holds for virtually all the years analyzed. This is much smaller than appears in the bivariate associations in Table 4 because in the bivariate associations the rural-urban variable in part is proxying for other characteristics, such as schooling attainment, type of employment contract, firm size, and type of economic activity. There are also regional effects relative to the Santiago metropolitan region (the omitted region in the specification). These regional effects vary from year to year, but their inclusion cleans the effects of the other explanatory variables from possible regional associations. 
Table 5

Regressions for the probability of making social security contributions (Dummy Dependent Variable $=1$ if individual is contributing and 0 otherwise)

\begin{tabular}{|c|c|c|c|c|c|}
\hline \multicolumn{6}{|l|}{$\begin{array}{l}\text { Variable } \\
\text { Gender: }\end{array}$} \\
\hline Gender: & & & & & \\
\hline \multicolumn{5}{|l|}{ Age: } & 0.0869 * \\
\hline$\overline{\text { Age }}$ & 0.0126 * & $0.0110 *$ & 0.0119 * & 0.0215 * & 0.0253 * \\
\hline \multicolumn{6}{|l|}{ Schooling attainment: } \\
\hline Complete Primary Schooling=1 & 0.0088 & $0.0286 *$ & 0.0123 & -0.0137 & $0.0270 *$ \\
\hline Incomplete Second.Schooling=1 & $0.0187^{* *}$ & $0.0302 *$ & 0.0056 & 0.0100 & 0.0129 \\
\hline Complete Second.Schooling=1 & $0.0560 *$ & $0.0625 *$ & 0.0486 * & $0.0460 *$ & 0.0685 * \\
\hline Incomplete Higher Education=1 & 0.0191 & 0.0054 & 0.0030 & $0.0444 *$ & 0.0559 * \\
\hline \multicolumn{5}{|l|}{ Geographical residence: } & $0.0377^{* *}$ \\
\hline Region $1=1$ & 0.0669 * & $0.0318 * *$ & 0.0241 & $0.0641 *$ & 0.0051 \\
\hline Region $2=1$ & 0.0546 * & 0.0213 & -0.0026 & 0.0297 & 0.0816 * \\
\hline Region $3=1$ & 0.0578 * & -0.0217 & 0.0683 * & $0.0860 *$ & 0.0126 \\
\hline Region 4=1 & 0.0183 & 0.0038 & $0.0287^{* *}$ & 0.0181 & 0.0571 * \\
\hline Region 5=1 & $0.0291 * *$ & $0.0229 * *$ & 0.0022 & $0.0437 *$ & 0.0225 \\
\hline Region $6=1$ & 0.0723 * & 0.0443 * & 0.0758 * & 0.0708 * & 0.0464 * \\
\hline Region $7=1$ & 0.0548 * & -0.0048 & 0.0059 & $0.0605 *$ & 0.0316 * \\
\hline Region $8=1$ & 0.0434 * & $0.0583 *$ & 0.0339 * & 0.0170 & 0.0071 \\
\hline Region $9=1$ & 0.0656 * & $-0.0549 *$ & -0.0218 & $0.0275 * *$ & 0.0011 \\
\hline Region $10=1$ & 0.0598 * & -0.0135 & -0.0494 * & $0.0379 *$ & 0.0544 * \\
\hline Region $11=1$ & 0.0932 * & -0.0012 & 0.0376 * & 0.0242 & 0.1162 * \\
\hline Region $12=1$ & 0.1066 * & $0.0697 *$ & 0.0955 * & $0.1593 *$ & 0.1162 * \\
\hline $\begin{array}{l}\text { Urban Zone }=1 \\
\text { Household head and marital status: }\end{array}$ & 0.0526 * & 0.0117 & 0.0544 * & 0.0406 * & 0.0331 * \\
\hline Head of Household=1 & 0.0796 * & 0.0403 * & 0.0639 * & $0.0413 *$ & 0.0814 * \\
\hline \multicolumn{6}{|l|}{ Sector of economic activity: } \\
\hline Mining=1 & 0.0110 & 0.0083 & -0.0042 & 0.0011 & -0.0319 \\
\hline Manufacturing=1 & 0.0206 & -0.0001 & 0.0252 & 0.0166 & -0.0079 \\
\hline Electricity,gas,water=1 & 0.0238 & -0.0484 & -0.0512 & -0.0186 & -0.0942 \\
\hline Construction=1 & $0.0565 *$ & 0.0643 * & 0.0388 * & 0.0509 * & 0.0277 \\
\hline Trade $=1$ & 0.0726 * & 0.0322 * & 0.0221 & $0.0663 *$ & $-0.0247^{* *}$ \\
\hline Transportation=1 & 0.0042 & -0.0213 & 0.0044 & -0.0102 & $-0.0785 *$ \\
\hline Financial Services $=1$ & $0.0911 *$ & $0.0635 *$ & 0.0576 * & $0.0711 *$ & 0.0070 \\
\hline Services $=1$ & 0.0181 & -0.0100 & -0.0085 & 0.0060 & 0.0709 * \\
\hline \multicolumn{6}{|l|}{ Firm Size: } \\
\hline 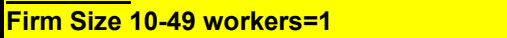 & 0.1133 * & 0.0837 * & 0.0662 * & $0.1077 *$ & 0.0750 * \\
\hline Firm Size 50-199 workers=1 & $0.1380 *$ & $0.1279 *$ & 0.0901 * & 0.1252 * & 0.1409 * \\
\hline \multicolumn{5}{|l|}{ Poverty: } & 0.2253 * \\
\hline$\overline{\text { Indigent }}=1$ & $-0.0520 *$ & $-0.0287 * *$ & $-0.0604 *$ & $-0.0747^{*}$ & $-0.0780 *$ \\
\hline \multicolumn{6}{|l|}{ Type of empl.contract \& type of worker: } \\
\hline Permanent Contract $=1$ & & $0.0640 *$ & 0.1209 * & $0.1337 *$ & 0.1551 * \\
\hline Temporary Contract (Plazo) $=1$ & & -0.0200 & -0.0121 & 0.0131 & 0.0077 \\
\hline Temporary Contract (Obra) $=1$ & & $-0.0736 *$ & -0.0109 & -0.0280 & -0.0348 \\
\hline It has signed contract=1 & 0.4960 * & 0.4776 * & 0.5624 * & 0.5298 * & 0.5246 * \\
\hline Employer=1 & 0.0170 & 0.0177 & 0.0845 * & 0.0673 * & 0.0895 * \\
\hline Self-employed $=1$ & $-0.1130 *$ & -0.0620 * & -0.0448 * & $-0.0736 *$ & -0.0753 * \\
\hline Domestic Service=1 & $-0.0329 * *$ & -0.0292 & $-0.0940 *$ & $-0.0824 *$ & -0.1478 * \\
\hline $\begin{array}{l}\text { Family worker=1 } \\
\text { Health insurance coverage: }\end{array}$ & $-0.1999 * *$ & $-0.2965 *$ & -0.2709 * & $-0.2549 *$ & -0.2193 * \\
\hline No health insurance $=1$ & $-0.0393 *$ & $-0.0534 *$ & 0.0213 & $-0.0249 *$ & $-0.0169 *$ \\
\hline Fonasa=1 (Public Health Insurance) & 0.3081 * & 0.2370 * & 0.3040 * & $0.2991 *$ & 0.0429 * \\
\hline Isapre=1 (Private Health Insurance) & $0.2841 *$ & $0.2297 *$ & 0.2857 * & $0.2590 *$ & 0.3464 * \\
\hline Number of observations & 44955 & 57827 & 45173 & 64251 & 80734 \\
\hline Pseudo-R ${ }^{2}$ & 0.5268 & 0.5136 & 0.5525 & 0.5664 & 0.6283 \\
\hline
\end{tabular}

Notes:a)Estimation Method: Probit with heteroskedasticity corrections;

b)Coefficients indicate the change in the probability as a consequence of a partial change in the explanatory variables (evaluated at mean values).

* Significant at $5 \% ;{ }^{* *}$ Significant at $10 \%$ 
Household head and marital status: The head of household has a probability of making contributions that is between 4 and 8 percentage points higher than nonheads, which is a little greater than appears in the bivariate associations in table 4. Being married, however, in the multivariate estimates is associated with a reduction of between 2 and 5 percentages points in being covered - the opposite of what is suggested by the bivariate estimates. Thus in the bivariate estimates marital status apparently is proxying in part for other characteristics associated with coverage. , while a permanent contract offers a strong positive relation with that probability.

Sector of economic activity: The economic activity controls (relative to the agricultural sector that is excluded from the equation) appear less significant in the multivariate than in the bivariate estimates. For example, once other variables are simultaneously controlled, neither the mining nor the community services sectors have higher coverage rates, as was suggested in Table 4.

Firm size: The firm size is positively associated with coverage probabilities in the multivariate estimates as in the bivariate estimates. But the association is less strong, suggesting that in the bivariate associations in part firm size is proxying for other characteristics such as schooling attainment and type of labor contract.

Poverty: $-\frac{P}{E}$ I multivariate controls, the probability of making contributions falls by between $\equiv$ d 7 percentage points for being indigent and by between 0 and 4 percentage points for being poor but not indigent. These are smaller amounts than indicated in the bivariate associations because the correlations between relative income and other important factors, such as the type of labor contract.

Type of employment contract and type of worker: The greatest association with converage in the multivariate estimates is indubitably having an employment contract, which, all else constant, increases the probability of making contributions by around 50 points. Therefore, the strong correlation observed in the bivariate tabulations in Table 4 is, if anything, stronger once there are multivariate controls. There is a further positive association of 6-15 percentage points with the contract being permanent, but - in contrast to the bivariate results - there no longer is a significant association with a fixed time contract. Once there are the other controls (including importantly the types of contracts), the association is much smaller, though still negative, with being a family worker, self-employed or in domestic service (relative to the excluded category of being a wage worker).

Health insurance coverage: Not having health insurance (or being classified as indigent for those effects) is generally associated with lower probabilities of making contributions. In contrast, being covered by FONASA (The Public Health System) or an ISAPRE (The Private Health System) have strong positive correlations with the probability of making contributions. The multivariate associations, however, once again are somewhat smaller than the bivariate ones in table 4, suggesting once again that in part health insurance coverage in the bivariate estimates is proxying for other factors such as employment contracts. 


\section{Characterization of and analysis of the determinants of the density of social security contributions and its dynamics}

In this section, we broaden our view to cover the density of contributions. As mentioned in the previous section, determining whether an individual contributed or not to the pension system in a given month does not provide us with a complete view of his/her coverage situation. The percentage of months in which an individual has made social security contributions as an adult, herein referred to as density of contributions, better represents his/her coverage as it pertains to the probability of obtaining pension benefits. However prior analysis has focused only on current contributions, not the cumulative density of contributions.

When attempting to estimate the density of contributions in the Chilean pension system, the usual problem is the lack of individual level information. However, by incorporating new information from the Employment History and Social Security Survey, this paper provides information that allows the density of contributions to be characterized.

\subsection{The Labor History and Social Security Survey (HLSS)}

In 2002, the Micro-data Center of the Department of Economics of the Universidad de Chile, conducted a new household survey (2002 HLSS, Historia Laboral y Seguridad Social) that provides useful information for addressing the main issue of this paper. The 2002 survey, financed by the Secretary of Labor and Social Security, contains information on 17,246 individuals affiliated to the retirement system at any time during the 1981-2001 time span ${ }^{3}$. Survey information collected includes sociodemographic data and current labor market data for each member of the household, detailed information about receipt of pensions and types of pension plan participation and retrospective labor market history going back to 1980.

The sampling frame of the 2002 HLSS survey consists of all individuals enrolled in the social security system for at least one month during the 1981-2001 time period. The sample included individuals who in 2002 were working, unemployed, out of the labor force, receiving pensions, or deceased (in this case the information was collected from surviving relatives). The sample was drawn from a sampling frame of approximately 8.1 million current and former affiliates of the social security system that was compiled from official databases (obtained from the Secretary of Labor and Social Security). This sample covers around $75 \%$ of the population aged 15 and older in 2001. The HLSS survey was applied between April and December of 2002.

The 2002 HLSS data contains rich information on household characteristics, earnings, labor force participation, assets, pension plan participation and savings. Particularly relevant for our purposes is the collection of retrospective data going back to 1980 on all employment, non-employment and unemployment spells. The 2002 HLSS questionnaire also contains some questions that are designed to directly elicit information about respondent's risk aversion.

\footnotetext{
${ }^{3}$ Information on the methodology and extent of the survey can be found in Bravo (2004).
} 


\subsection{Estimating and characterizing the density of contributions}

In this section we characterize the dynamics of Social Security contributions over 20 years of experience. As already stated, the interviewees provided information on their employment and social security contribution situation dating back to January 1980. The density of contribution indicators were calculated by adding the number of months since January 1980 in which the interviewees declared having made pension system contributions and then dividing that by the number of months in which individuals were older than 15 since January 1980. the estimated individual contribution densities bas $\epsilon$ ble 6 shows the distribution of our calculations .

Table 6

Distribution of the Density of Contributions from 1980 (or later) and 2002

\begin{tabular}{|cc|}
\hline Percentile & Density of Contributions \\
\hline $5 \%$ & \\
$10 \%$ & $0.0 \%$ \\
$15 \%$ & $1.1 \%$ \\
$20 \%$ & $6.0 \%$ \\
$25 \%$ & $12.9 \%$ \\
$30 \%$ & $19.8 \%$ \\
$35 \%$ & $27.1 \%$ \\
$40 \%$ & $34.4 \%$ \\
$45 \%$ & $41.3 \%$ \\
$50 \%$ & $47.6 \%$ \\
$55 \%$ & $54.2 \%$ \\
$60 \%$ & $60.3 \%$ \\
$65 \%$ & $66.4 \%$ \\
$70 \%$ & $72.4 \%$ \\
$75 \%$ & $78.5 \%$ \\
$80 \%$ & $85.2 \%$ \\
$85 \%$ & $92.6 \%$ \\
$90 \%$ & $99.3 \%$ \\
$95 \%$ & $100.0 \%$ \\
& $100.0 \%$ \\
Average & \\
& $52.4 \%$ \\
\hline
\end{tabular}

Table 6 shows that on average the affiliates surveyed reported having made pension system contributions in $52 \%$ of months. The average density registered is significantly lower than what is usually used in pension simulation and projection exercises for representative individuals, which usually is $80 \%$ or more. Table 6 shows that only around $30 \%$ of affiliates reported having or surpassing that density of contributions.

However, the low average density of contributions is not the only noteworthy aspect observable in Table 6 . The form of the distribution of this parameter in the population is also notable. To observe this more clearly, figure 1 contains a nonparametric graph of the distribution of the density of contributions according to the self-reporting of the interviewees. 


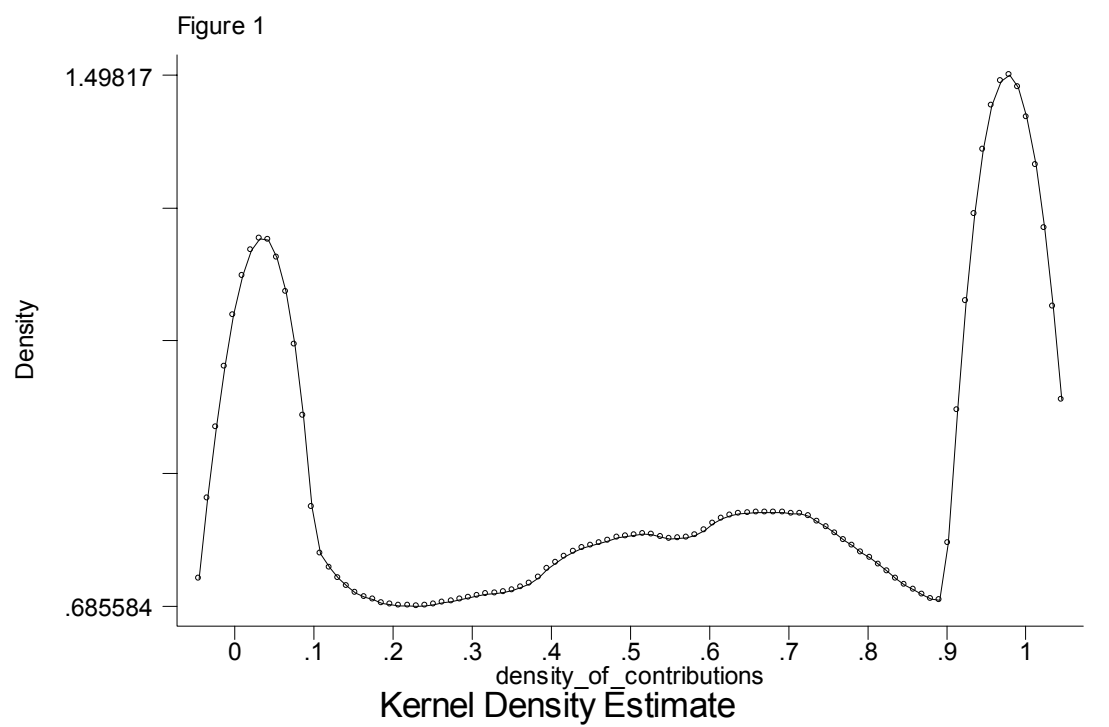

This distribution is clearly bimodal: part of the population (approximately $15 \%$ ) has a density of contributions approaching 0 , while another significant group (approximately 15\%) $\stackrel{-\rho}{=}$ a contribution density approaching $100 \%$.

To delve further into the characteristics associated with the general profile of the density of contributions, Table 7 has information on the average density as well as on another three points of the distribution (percentiles 25, 50 and 75) for different socio-demographic variables. The information in Table 7 is complemented by the decomposition of the density of contributions indicator in Table 8. In effect, if the density of contributions of an individual $i$ is defined as the number of months with contributions $\left(\mathrm{c}_{\mathrm{i}}\right)$ as a percentage of the total number of months in which individual $i$ was 15 years old or older $\left(m_{i}\right)$ :

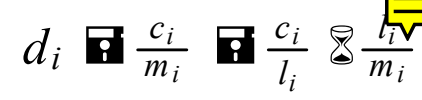

then, the density may be written as the product of the pension coverage of individual $\mathrm{i}$ in the months worked $\left(\mathrm{c}_{\mathrm{i}} / \mathrm{l}_{\mathrm{i}}\right)$ and the percentage of months in the adult working history in which individual $\mathrm{i}$ was working $\left(\mathrm{I}_{\mathrm{i}} / \mathrm{m}_{\mathrm{i}}\right)$.

Current work and pension status: The average density of contributions over the last 20 years for affiliates with a pension but who continue working $(64 \%)$ is higher than that of those working who do not yet receive a pension (53\%). On the other hand, pensioners who have pulled out of the labor market have a lower density $(41 \%) .{ }^{4}$ That pensioners who are outside the labor market have a lower density is related to their leaving the labor market (as may be observed in Table 8): they have a much lower employment rate than the other categories, even though their contribution rate to the pension system was very high when they were working (possibly because their work was right before their retirement).

\footnotetext{
4 It should be noted that in Chile, it is not necessary to quit working to receive a pension. In such a stituation, however, continuing pension contributions is voluntary.
} 
Table 7

Density of Contributions: Characterization

\begin{tabular}{|c|c|c|c|c|}
\hline \multirow[b]{2}{*}{ Variable } & \multirow[b]{2}{*}{ Mean } & \multicolumn{3}{|c|}{ Percentile } \\
\hline & & $25 \%$ & $50 \%$ & $75 \%$ \\
\hline 1. Total & $52.4 \%$ & $19.8 \%$ & $54.2 \%$ & $85.2 \%$ \\
\hline \multicolumn{5}{|l|}{ 2. Current Status: } \\
\hline -Active (not retired) & $53.3 \%$ & $22.2 \%$ & $54.8 \%$ & $85.4 \%$ \\
\hline -With pension and in the labor force & $64.2 \%$ & $35.6 \%$ & $74.5 \%$ & $100.0 \%$ \\
\hline -Retired only with pension & $41.4 \%$ & $0.0 \%$ & $40.5 \%$ & $76.3 \%$ \\
\hline \multicolumn{5}{|l|}{ 3. Sex: } \\
\hline -Men & $59.8 \%$ & $31.5 \%$ & $65.7 \%$ & $92.7 \%$ \\
\hline -Women & $43.8 \%$ & $11.3 \%$ & $40.2 \%$ & $72.3 \%$ \\
\hline \multicolumn{5}{|l|}{ 4. Age: } \\
\hline$-15-18$ years & $19.2 \%$ & $5.6 \%$ & $12.5 \%$ & $25.7 \%$ \\
\hline$-19-24$ years & $35.2 \%$ & $12.5 \%$ & $31.1 \%$ & $52.8 \%$ \\
\hline$-25-34$ years & $47.0 \%$ & $23.6 \%$ & $47.7 \%$ & $68.8 \%$ \\
\hline$-35-44$ years & $56.0 \%$ & $27.8 \%$ & $60.7 \%$ & $84.2 \%$ \\
\hline$-45-54$ years & $66.8 \%$ & $33.5 \%$ & $83.7 \%$ & $100.0 \%$ \\
\hline$-55-64$ years & $63.4 \%$ & $28.3 \%$ & $77.9 \%$ & $100.0 \%$ \\
\hline-65 and older & $38.7 \%$ & $0.0 \%$ & $31.1 \%$ & $75.6 \%$ \\
\hline \multicolumn{5}{|l|}{ 5. Schooling: } \\
\hline -None & $31.3 \%$ & $0.0 \%$ & $9.3 \%$ & $61.5 \%$ \\
\hline -Primary Incomplete & $47.6 \%$ & $4.4 \%$ & $46.7 \%$ & $89.2 \%$ \\
\hline -Primary Complete & $52.2 \%$ & $17.2 \%$ & $53.7 \%$ & $87.5 \%$ \\
\hline -Secondary Incomplete & $54.7 \%$ & $22.1 \%$ & $57.8 \%$ & $87.8 \%$ \\
\hline -Secondary Complete & $55.7 \%$ & $28.9 \%$ & $58.8 \%$ & $82.7 \%$ \\
\hline -Vocational Higher Education & $52.3 \%$ & $28.1 \%$ & $53.2 \%$ & $75.9 \%$ \\
\hline -University Incomplete & $44.8 \%$ & $13.3 \%$ & $43.1 \%$ & $71.8 \%$ \\
\hline -University Complete & $63.8 \%$ & $37.0 \%$ & $68.1 \%$ & $99.3 \%$ \\
\hline
\end{tabular}


Table 7 (cont.)

Density of Contributions: Characterization

\begin{tabular}{|c|c|c|c|c|}
\hline \multirow[b]{2}{*}{ Variable } & \multirow[b]{2}{*}{ Mean } & \multicolumn{3}{|c|}{ Percentile } \\
\hline & & $25 \%$ & $50 \%$ & $75 \%$ \\
\hline \multicolumn{5}{|l|}{ 6. Head of Household: } \\
\hline -Head & $59.5 \%$ & $29.2 \%$ & $66.4 \%$ & $94.8 \%$ \\
\hline -Non Head & $43.1 \%$ & $13.3 \%$ & $39.7 \%$ & $68.8 \%$ \\
\hline \multicolumn{5}{|l|}{ 7. Marriage Status: } \\
\hline -Single & $45.2 \%$ & $16.1 \%$ & $43.3 \%$ & $69.7 \%$ \\
\hline -Married, widow, divorced & $54.7 \%$ & $21.8 \%$ & $58.2 \%$ & $89.3 \%$ \\
\hline \multicolumn{5}{|l|}{ 8. Current Occupational Status: } \\
\hline -Employed & $61.2 \%$ & $35.3 \%$ & $65.5 \%$ & $94.1 \%$ \\
\hline -Unemployed & $45.7 \%$ & $17.4 \%$ & $43.3 \%$ & $72.7 \%$ \\
\hline -Out of the Labor Force & $33.7 \%$ & $0.7 \%$ & $23.5 \%$ & $59.8 \%$ \\
\hline \multicolumn{5}{|c|}{ 9. Per Capita Total Household Income: } \\
\hline -Quintile 1 (lower) & $42.7 \%$ & $8.8 \%$ & $36.7 \%$ & $75.2 \%$ \\
\hline -Quintile 2 & $46.7 \%$ & $12.7 \%$ & $45.2 \%$ & $78.8 \%$ \\
\hline -Quintile 3 & $52.6 \%$ & $20.5 \%$ & $55.0 \%$ & $85.0 \%$ \\
\hline -Quintile 4 & $56.8 \%$ & $28.5 \%$ & $60.0 \%$ & $89.0 \%$ \\
\hline -Quintile 5 (higher) & $60.8 \%$ & $34.8 \%$ & $65.5 \%$ & $95.6 \%$ \\
\hline
\end{tabular}

Source: Elaborated using HLSS Survey.

Gender: Table 7 shows that the average density of contributions of men is 16 percentage points higher than that of women. This difference exists in all points of the distribution. Thus, for example, if individuals were ordered by density of contributions, men from percentile 10 have a density of $32 \%$ compared with the same percentile for women that reaches an $11 \%$ density. Table 8 shows that the lower density for women is attributed to the lower employment rate of women in the reference period. In contrast, in periods when men and women both declare working, women have higher contribution rates than men.

Age: in contrast to the age patterns in Table 4 with the highest values for young workers, Table 7 shows that the density of contributions, for the average and for the different percentiles, follows a monotonic pattern until approximately 60 years of age, when people start to receive their pensions ${ }^{5}$. For the 65 and over group, which covers most pensioners, contribution densities are lower. This could be due in part to the fact that, as was mentioned earlier, pensioners do not have to make contributions to the pension system. 8 provides complementary information, indicating that the increasing density : is (at least until 54 years old), at least partially, due to the increasing employment rate.

\footnotetext{
${ }^{5}$ Even though the legal pension age is 60 for women and 65 for men, it is possible to obtain a pension earlier in the AFP system once certain criteria are fulfilled: (a) Getting a pension equal to or above $110 \%$ of the minimum pension guaranteed by the State; and (b) the pension is equal to or above $50 \%$ of the average of the taxable income of the last 10 years of work (inflation adjusted).
} 
Table 8

Density of Contributions: Decomposition

\begin{tabular}{|c|c|c|c|}
\hline Variable & $d_{i}$ & $\frac{c_{i}}{l_{i}}$ & $\frac{l_{i}}{m_{i}}$ \\
\hline 1. Total & $52.4 \%$ & $84.4 \%$ & $64.6 \%$ \\
\hline \multicolumn{4}{|l|}{ 2. Current Status: } \\
\hline -Active (not retired) & $53.3 \%$ & $83.7 \%$ & $66.7 \%$ \\
\hline -With pension and in the labor force & $64.2 \%$ & $74.6 \%$ & $87.7 \%$ \\
\hline -Retired only with pension & $41.4 \%$ & $97.2 \%$ & $40.5 \%$ \\
\hline \multicolumn{4}{|l|}{ 3. Sex: } \\
\hline -Men & $59.8 \%$ & $80.8 \%$ & $76.1 \%$ \\
\hline -Women & $43.8 \%$ & $89.0 \%$ & $51.2 \%$ \\
\hline \multicolumn{4}{|l|}{ 4. Age: } \\
\hline$-15-18$ years & $19.2 \%$ & $80.2 \%$ & $28.4 \%$ \\
\hline$-19-24$ years & $35.2 \%$ & $82.0 \%$ & $44.0 \%$ \\
\hline$-25-34$ years & $47.0 \%$ & $84.6 \%$ & $57.8 \%$ \\
\hline$-35-44$ years & $56.0 \%$ & $83.9 \%$ & $71.0 \%$ \\
\hline$-45-54$ years & $66.8 \%$ & $87.5 \%$ & $82.1 \%$ \\
\hline$-55-64$ years & $63.4 \%$ & $81.2 \%$ & $77.1 \%$ \\
\hline-65 and older & $38.7 \%$ & $85.3 \%$ & $45.2 \%$ \\
\hline \multicolumn{4}{|l|}{ 5. Schooling: } \\
\hline -None & $31.3 \%$ & $71.2 \%$ & $44.2 \%$ \\
\hline -Primary Incomplete & $47.6 \%$ & $79.0 \%$ & $63.0 \%$ \\
\hline -Primary Complete & $52.2 \%$ & $77.3 \%$ & $70.3 \%$ \\
\hline -Secondary Incomplete & $54.7 \%$ & $79.8 \%$ & $68.9 \%$ \\
\hline -Secondary Complete & $55.7 \%$ & $91.0 \%$ & $65.4 \%$ \\
\hline -Vocational Higher Education & $52.3 \%$ & $89.8 \%$ & $59.8 \%$ \\
\hline -University Incomplete & $44.8 \%$ & $80.6 \%$ & $56.5 \%$ \\
\hline -University Complete & $63.8 \%$ & $91.7 \%$ & $70.0 \%$ \\
\hline \multicolumn{4}{|l|}{ 6. Head of Household: } \\
\hline -Head & $59.5 \%$ & $83.2 \%$ & $74.1 \%$ \\
\hline -Non Head & $43.1 \%$ & $86.0 \%$ & $52.2 \%$ \\
\hline \multicolumn{4}{|l|}{ 7. Marriage Status: } \\
\hline -Single & $45.2 \%$ & $81.5 \%$ & $57.0 \%$ \\
\hline -Married, widow, divorced & $54.7 \%$ & $85.3 \%$ & $67.0 \%$ \\
\hline \multicolumn{4}{|l|}{ 8. Per Capita Total Household Income: } \\
\hline -Quintile 1 (lower) & $42.7 \%$ & $76.8 \%$ & $58.1 \%$ \\
\hline -Quintile 2 & $46.7 \%$ & $77.6 \%$ & $61.5 \%$ \\
\hline -Quintile 3 & $52.6 \%$ & $85.6 \%$ & $64.0 \%$ \\
\hline -Quintile 4 & $56.8 \%$ & $92.1 \%$ & $67.6 \%$ \\
\hline -Quintile 5 (higher) & $60.8 \%$ & $87.6 \%$ & $70.4 \%$ \\
\hline
\end{tabular}

Source: Elaborated using HLSS Survey. 
Schooling attainment: The density of contributions of affiliates with secondary education is higher than that of those with only primary education, and they are in turn above those without any education. In line with this pattern, affiliates with full university education have the highest density of contributions. However, this tendency for higher density with more schooling is broken by higher vocational education and incomplete university studies: in these cases, the density of contributions is similar to that of affiliates with only primary education (both on average and for the percentiles shown).

Household head and marital status: The densities of contributions for heads of households are significantly higher than that of other members of the household. This is consistent with what may be observed in Tables 4 and 5 when using a simpler coverage indicator. This basically reflects the much higher employment rate of the heads of households (Table 8 ). Those married have higher density than those not. This differential contrasts with the relatively lower and more unstable one shown in Tables 4 and 5 when using the proportion of contributors. Once again, the most relevant element for explaining the difference between these two groups is the higher employment rate of married individuals.

Employment status at time of survey: The average density for those employed exceeds $60 \%$, while the level for those unemployed was 15 points lower and 27 point lower for those who at the time of the survey were out of the labor force.

Income distribution: The lowest densities of contribution are concentrated in individuals who live in the lowest income households. In fact, if households are ranked by the total per capita income reported in the survey, the median of the density is $37 \%$ for the lowest income quintile and $66 \%$ for the highest quintile. This pattern is analogous to that shown by the coverage indicator of Table 4: the poorest households not only have a lower probability of making contributions at any given point in time, but they are also associated with lower accumulated contributions.

Table 9 shows the contribution densities of the individuals surveyed, separated by social security systems: AFP and INP (the affiliates who opted to stay in the old pension system).

In general, the densities shown by affiliates of the AFP system are higher than those of the current affiliates of the INP system. This becomes even more marked when comparing the densities by age group or by status, which allows us to better isolate the heterogeneity of those sub-samples. It should be kept in mind however, that causal effects of the AFP system cannot be deduced from this Table, since there may be a selection bias in the transfer process from the old system ${ }^{6}$.

Table 10 reports the density of contributions for different characteristics only of the workers who declared being actively employed in the survey. The characteristics refer only to the last job reported, but are more reflective of the longer-run work history if there is serial correlation in such characteristics over the life cycle (e.g., due to state dependence).

\footnotetext{
${ }^{6}$ For example, these figures could be showing that those who opted to switch to the AFP system were individuals with higher densities of contribution.
} 
Table 9

Density of Contributions: AFP and INP

\begin{tabular}{|c|c|c|c|c|}
\hline \multirow[b]{2}{*}{ Variable } & \multirow[b]{2}{*}{ Mean } & \multicolumn{3}{|c|}{ Percentile } \\
\hline & & $25 \%$ & $50 \%$ & $75 \%$ \\
\hline 1. Total & $52.4 \%$ & $19.8 \%$ & $54.2 \%$ & $85.2 \%$ \\
\hline 2. AFP System: & $56.0 \%$ & $27.8 \%$ & $57.9 \%$ & $86.1 \%$ \\
\hline \multicolumn{5}{|l|}{ 2.1. By Age: } \\
\hline$-15-18$ years & $19.8 \%$ & $8.3 \%$ & $16.7 \%$ & $25.7 \%$ \\
\hline$-19-24$ years & $35.7 \%$ & $13.1 \%$ & $31.7 \%$ & $53.3 \%$ \\
\hline$-25-34$ years & $47.4 \%$ & $24.4 \%$ & $47.9 \%$ & $69.0 \%$ \\
\hline$-35-44$ years & $57.2 \%$ & $30.0 \%$ & $62.2 \%$ & $84.8 \%$ \\
\hline$-45-54$ years & $70.2 \%$ & $43.6 \%$ & $86.7 \%$ & $100.0 \%$ \\
\hline$-55-64$ years & $71.1 \%$ & $48.4 \%$ & $84.4 \%$ & $100.0 \%$ \\
\hline-65 and older & $61.2 \%$ & $40.4 \%$ & $64.1 \%$ & $88.9 \%$ \\
\hline \multicolumn{5}{|l|}{ 2.2 By Status: } \\
\hline -Active (not retired) & $55.0 \%$ & $26.4 \%$ & $56.3 \%$ & $85.1 \%$ \\
\hline -With pension and in the labor force & $70.8 \%$ & $50.2 \%$ & $81.9 \%$ & $100.0 \%$ \\
\hline -Retired only with pension & $61.1 \%$ & $44.8 \%$ & $65.8 \%$ & $83.2 \%$ \\
\hline 3. INP (Old pension system): & $40.5 \%$ & $0.0 \%$ & $28.8 \%$ & $84.1 \%$ \\
\hline \multicolumn{5}{|l|}{ 3.1. By Age: } \\
\hline$-35-44$ years & $36.0 \%$ & $0.0 \%$ & $25.5 \%$ & $67.0 \%$ \\
\hline$-45-54$ years & $52.2 \%$ & $4.5 \%$ & $57.6 \%$ & $100.0 \%$ \\
\hline$-55-64$ years & $52.0 \%$ & $0.0 \%$ & $54.3 \%$ & $98.5 \%$ \\
\hline-65 and older & $33.2 \%$ & $0.0 \%$ & $13.8 \%$ & $66.7 \%$ \\
\hline \multicolumn{5}{|l|}{ 3.2 By Status: } \\
\hline -Active (not retired) & $44.9 \%$ & $0.0 \%$ & $32.5 \%$ & $100.0 \%$ \\
\hline -With pension and in the labor force & $53.2 \%$ & $8.8 \%$ & $55.2 \%$ & $99.3 \%$ \\
\hline -Retired only with pension & $34.3 \%$ & $0.0 \%$ & $21.4 \%$ & $68.6 \%$ \\
\hline
\end{tabular}

Source: Elaborated using HLSS Survey.

Current employment category, occupation and economic activity: The low densities of contribution of non-remunerated and independent workers stand out (and to a lesser extent, domestic service workers), in comparison with employers and wage workers. Likewise, the low density is more evident among unskilled workers, salespeople, agricultural and service workers among occupations and among those who were working at the time of the survey in the agricultural and retail sectors with regard to economic activity. 
Table 10

Density of Contributions for currently employed

\begin{tabular}{|c|c|c|c|c|}
\hline \multirow[b]{2}{*}{ Variable } & \multirow[b]{2}{*}{ Mean } & \multicolumn{3}{|c|}{ Percentile } \\
\hline & & $25 \%$ & $50 \%$ & $75 \%$ \\
\hline 1. Total & $61.2 \%$ & $35.3 \%$ & $65.5 \%$ & $94.1 \%$ \\
\hline \multicolumn{5}{|l|}{ 2. Current Employment Category: } \\
\hline -Employer & $60.8 \%$ & $26.3 \%$ & $68.1 \%$ & $100.0 \%$ \\
\hline -Self-employed & $45.1 \%$ & $8.9 \%$ & $42.1 \%$ & $78.4 \%$ \\
\hline -Wage Worker & $65.8 \%$ & $43.9 \%$ & $69.3 \%$ & $95.9 \%$ \\
\hline -Domestic Service & $52.2 \%$ & $19.6 \%$ & $52.6 \%$ & $89.0 \%$ \\
\hline -Family worker (without wage) & $35.3 \%$ & $11.8 \%$ & $22.7 \%$ & $61.9 \%$ \\
\hline \multicolumn{5}{|l|}{ 3. Current Occupation: } \\
\hline -Managers & $58.8 \%$ & $26.1 \%$ & $61.3 \%$ & $100.0 \%$ \\
\hline -Professionals & $65.3 \%$ & $40.3 \%$ & $68.8 \%$ & $100.0 \%$ \\
\hline -Technicians/medium level profess. & $60.4 \%$ & $38.4 \%$ & $63.2 \%$ & $85.0 \%$ \\
\hline -White collar workers & $64.8 \%$ & $43.3 \%$ & $68.3 \%$ & $91.5 \%$ \\
\hline -Sales and service workers & $55.0 \%$ & $26.8 \%$ & $55.9 \%$ & $83.6 \%$ \\
\hline -Agricultural workers & $53.2 \%$ & $13.3 \%$ & $56.4 \%$ & $94.4 \%$ \\
\hline -Blue collar workers & $64.0 \%$ & $41.2 \%$ & $70.0 \%$ & $95.5 \%$ \\
\hline -Machine operators & $68.8 \%$ & $48.1 \%$ & $74.9 \%$ & $98.5 \%$ \\
\hline -Non-skilled workers & $58.4 \%$ & $28.0 \%$ & $60.6 \%$ & $94.4 \%$ \\
\hline \multicolumn{5}{|l|}{ 4. Current Economic Activity: } \\
\hline -Agriculture & $58.1 \%$ & $22.1 \%$ & $64.1 \%$ & $98.2 \%$ \\
\hline -Mining & $74.0 \%$ & $57.0 \%$ & $78.6 \%$ & $100.0 \%$ \\
\hline -Manufacturing & $67.0 \%$ & $46.8 \%$ & $72.0 \%$ & $95.8 \%$ \\
\hline -Electricity,gas and water & $74.0 \%$ & $50.9 \%$ & $84.4 \%$ & $100.0 \%$ \\
\hline -Construction & $64.0 \%$ & $39.5 \%$ & $69.4 \%$ & $95.1 \%$ \\
\hline -Trade & $55.4 \%$ & $28.1 \%$ & $57.8 \%$ & $84.8 \%$ \\
\hline -Transport and Communications & $61.9 \%$ & $38.6 \%$ & $67.0 \%$ & $91.5 \%$ \\
\hline -Financial Services & $60.8 \%$ & $38.2 \%$ & $63.6 \%$ & $87.5 \%$ \\
\hline -Services & $61.2 \%$ & $33.3 \%$ & $64.8 \%$ & $99.1 \%$ \\
\hline
\end{tabular}


Table 10 (cont.)

Density of Contributions for currently employed

\begin{tabular}{|c|c|c|c|c|}
\hline \multirow[b]{2}{*}{ Variable } & \multirow[b]{2}{*}{ Mean } & \multicolumn{3}{|c|}{ Percentile } \\
\hline & & $25 \%$ & $50 \%$ & $75 \%$ \\
\hline \multicolumn{5}{|l|}{ 5. Labor Contract in Current Employment: } \\
\hline -Yes & $69.4 \%$ & $49.0 \%$ & $73.1 \%$ & $99.2 \%$ \\
\hline- No & $42.9 \%$ & $11.9 \%$ & $40.1 \%$ & $69.5 \%$ \\
\hline \multicolumn{5}{|l|}{ 6. Firm Size in current employment: } \\
\hline-1 worker & $47.3 \%$ & $11.9 \%$ & $44.4 \%$ & $81.5 \%$ \\
\hline$-2-9$ workers & $56.7 \%$ & $26.6 \%$ & $58.8 \%$ & $91.5 \%$ \\
\hline$-10-19$ workers & $65.7 \%$ & $43.8 \%$ & $69.8 \%$ & $96.3 \%$ \\
\hline$-20-49$ workers & $66.8 \%$ & $46.9 \%$ & $69.7 \%$ & $96.7 \%$ \\
\hline$-50-99$ workers & $67.6 \%$ & $46.7 \%$ & $72.4 \%$ & $99.3 \%$ \\
\hline$-100-199$ workers & $67.8 \%$ & $46.8 \%$ & $72.1 \%$ & $95.2 \%$ \\
\hline$-200-499$ workers & $68.8 \%$ & $46.8 \%$ & $72.9 \%$ & $97.4 \%$ \\
\hline-500 and + workers & $68.1 \%$ & $48.1 \%$ & $71.8 \%$ & $99.3 \%$ \\
\hline \multicolumn{5}{|l|}{ 7. Weekly hours of work in current empl.: } \\
\hline$-0-20$ hours & $39.5 \%$ & $8.9 \%$ & $33.3 \%$ & $64.9 \%$ \\
\hline$-21-30$ hours & $50.7 \%$ & $18.5 \%$ & $47.8 \%$ & $86.4 \%$ \\
\hline$-31-39$ hours & $54.4 \%$ & $23.4 \%$ & $52.0 \%$ & $90.7 \%$ \\
\hline$-40-48$ hours & $66.0 \%$ & $44.4 \%$ & $69.7 \%$ & $97.0 \%$ \\
\hline$-49-60$ hours & $61.0 \%$ & $35.0 \%$ & $66.3 \%$ & $95.2 \%$ \\
\hline-61 and + hours & $62.4 \%$ & $35.3 \%$ & $68.9 \%$ & $97.9 \%$ \\
\hline \multicolumn{5}{|c|}{ 8. Hourly wage by quintile in current empl.: } \\
\hline -Quintile 1 (lower) & $50.6 \%$ & $17.4 \%$ & $50.0 \%$ & $85.6 \%$ \\
\hline -Quintile 2 & $61.5 \%$ & $36.7 \%$ & $64.4 \%$ & $93.3 \%$ \\
\hline -Quintile 3 & $63.4 \%$ & $41.0 \%$ & $67.4 \%$ & $93.1 \%$ \\
\hline -Quintile 4 & $65.4 \%$ & $44.6 \%$ & $70.2 \%$ & $94.5 \%$ \\
\hline -Quintile 5 (higher) & $68.5 \%$ & $47.0 \%$ & $73.1 \%$ & $100.0 \%$ \\
\hline \multicolumn{5}{|l|}{ 9. Type of current employment: } \\
\hline -Permanent & $63.4 \%$ & $38.8 \%$ & $68.2 \%$ & $96.3 \%$ \\
\hline -Temporary & $52.0 \%$ & $19.9 \%$ & $54.4 \%$ & $83.8 \%$ \\
\hline -Transitory ("a plazo fijo") & $55.9 \%$ & $30.0 \%$ & $57.6 \%$ & $82.6 \%$ \\
\hline -Transitory ("por tarea o servicio") & $49.7 \%$ & $18.9 \%$ & $48.5 \%$ & $79.8 \%$ \\
\hline
\end{tabular}

Source: Elaborated using HLSS Survey.

Labor contracts: Employees currently working with contracts also have the highest densities of contributions.

Firm size: Workers in companies with less than 10 employees have the lowest densities; workers in larger companies have densities of contributions that are relatively similar among each other.

Weekly hours of work: In concordance with the coverage indicators of Table 4, the highest densities of contributions increase with the extension of the working week up to 48 hours, after which they fall off for longer working hours. 
Type of employment contract: Employees in jobs they themselves consider permanent have higher densities of contributions than those with temporary positions.

Wage rates: Those with higher wage rates in their current employment also have higher densities of contributions. The sharpest gradient, as above, is between the bottom and the next lowest part (quintile in this case) of the distribution.

Table 11 links the concept of coverage used in the section 3 with that of density of contributions from this section. Currently employed workers that made social security contributions in the previous month have a higher average density of contributions $(70 \%)$ than those who did not contribute $(38 \%)$, thus, illustrating again the serial correlation over time in contributions. Nevertheless, it should also be noted that $25 \%$ of the workers who did not make contributions in the preceding month in fact have a density of contributions above $64 \%$. Analogously, $25 \%$ of those that report having made contributions in the preceding month have densities of contributions below $50 \%$ in the last 20 years.

Table 11

Density of Contributions by last month coverage

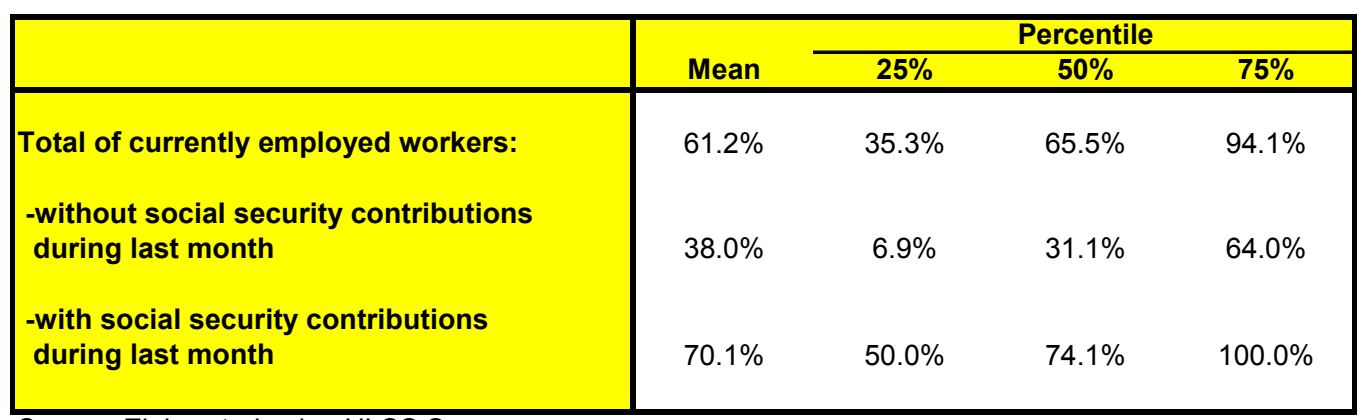

Source: Elaborated using HLSS Survey.

Using the self-reporting of the employment history for the last 20 years, it is possible to analyze all the periods of the different individuals surveyed, in which they declared working in different employment categories.

Table 12 illustrates mobility among employment categories over time. It shows, for example, that among the workers that worked as salaried workers in some month, $17 \%$ also worked as self-employed (at least one month in their employment history of the last 20 years), $2.8 \%$ as employers, $5.7 \%$ as domestic workers and less than $1 \%$ as non-remunerated family members. Among those who reported having had at least one month as independent workers, $74 \%$ also worked as salaried workers. Only 23\% reported having worked only as self-employed workers since 1980 . 
Table 12

Job Market Experience in different employment categories

\begin{tabular}{|l|rcccc|}
\hline \multicolumn{1}{|c|}{$\begin{array}{c}\text { Considering the total } \\
\text { who worked at least 1 } \\
\text { month in each category: }\end{array}$} & \multicolumn{5}{|c}{ Other categories where they have worked: } \\
\cline { 2 - 5 } Wage-worker (WW) & WW & SE & EM & DS & FW \\
Self/employed (SE) & $100 \%$ & $17.2 \%$ & $2.8 \%$ & $5.7 \%$ & $0.8 \%$ \\
Employer (EM) & $74.3 \%$ & $100 \%$ & $2.4 \%$ & $4.5 \%$ & $0.9 \%$ \\
Domestic Service (DS) & $61.4 \%$ & $12.5 \%$ & $100 \%$ & $1.3 \%$ & $0.8 \%$ \\
Non-remunerated & $48.5 \%$ & $8.9 \%$ & $0.5 \%$ & $100.0 \%$ & $0.3 \%$ \\
family worker (FW) & $87.0 \%$ & $22.6 \%$ & $4.0 \%$ & $4.1 \%$ & $100.0 \%$ \\
\hline
\end{tabular}

Source: Elaborated using HLSS Survey.

Table 13 compares the density of contributions for the different employment categories by using the information from the self-reported employment history of those surveyed. This Table was built by computing the density of contributions for each individual for each employment category in which they may have worked (as is shown in Table 12, the interviewees, in fact, report being in several categories at a time). Table 13 shows the averages for the total and for different percentiles of the distribution.

Table 13

Density of contributions in months worked in different employment categories

\begin{tabular}{|c|c|c|c|c|}
\hline \multirow[b]{2}{*}{ Percentile } & \multicolumn{4}{|c|}{ Density of contributions in months worked as: } \\
\hline & $\begin{array}{c}\text { Wage } \\
\text { Worker }\end{array}$ & $\begin{array}{c}\text { Self- } \\
\text { Employed }\end{array}$ & Employer & $\begin{array}{c}\text { Domestic } \\
\text { Service }\end{array}$ \\
\hline Mean & $87.6 \%$ & $23.9 \%$ & $51.3 \%$ & $62.4 \%$ \\
\hline $\begin{array}{l}\text { Percentile: } \\
5 \%\end{array}$ & $15.7 \%$ & $0 \%$ & $0 \%$ & $0 \%$ \\
\hline $10 \%$ & $48.1 \%$ & $0 \%$ & $0 \%$ & $0 \%$ \\
\hline $25 \%$ & $92.2 \%$ & $0 \%$ & $0 \%$ & $0 \%$ \\
\hline $50 \%$ & $100 \%$ & $0 \%$ & $75.8 \%$ & $100 \%$ \\
\hline $75 \%$ & $100 \%$ & $25.5 \%$ & $100 \%$ & $100 \%$ \\
\hline $90 \%$ & $100 \%$ & $100 \%$ & $100 \%$ & $100 \%$ \\
\hline $95 \%$ & $100 \%$ & $100 \%$ & $100 \%$ & $100 \%$ \\
\hline $\mathrm{N}^{\circ}$ Observations & 13422 & 3185 & 574 & 1533 \\
\hline
\end{tabular}

Source: Elaborated using HLSS Survey. 
Table 13 confirms the importance of the employment category in the probability of making contributions into the pension system. When only the months in the salaried category for each individual are considered, the distribution is heavily biased, with an average density of contributions of $88 \%$. In fact, it may be observed that $75 \%$ of individuals report having densities of over $92 \%$. The opposite applies for those months worked in the self-employment category. In this case, $50 \%$ of individuals registered a density of 0 and $75 \%$ have densities below $25 \%$. Nevertheless, $10 \%$ declared having made contributions all the months in which they worked independently.

In the case of the months in which individuals were employers or worked as domestic help, the densities show an intermediate situation with markedly bimodal distributions: with regard to employers, while $25 \%$ of individuals did not make contributions, another equivalent percentage had a density of $100 \%$; lastly, $50 \%$ of domestic help workers indicated they had a density of $100 \%$ even though $25 \%$ stated they had not made any contributions.

The survey also allows the evaluation of the importance of sub declaration of contributions. Out of the total months in which individuals worked as salaried employees and made contributions, $85 \%$ of these contributions were for the total of the remuneration. Of the other $15 \%$, the contribution for most months took the minimum wage as the base. The sub declaration rate approaches $40 \%$ in the case of periods worked in the employer category, while for periods worked as independent workers, Figure 2 suggest that when social security contributions are made, approximately $55 \%$ do so for a remuneration below the amount actually earned (typically for the minimum wage).

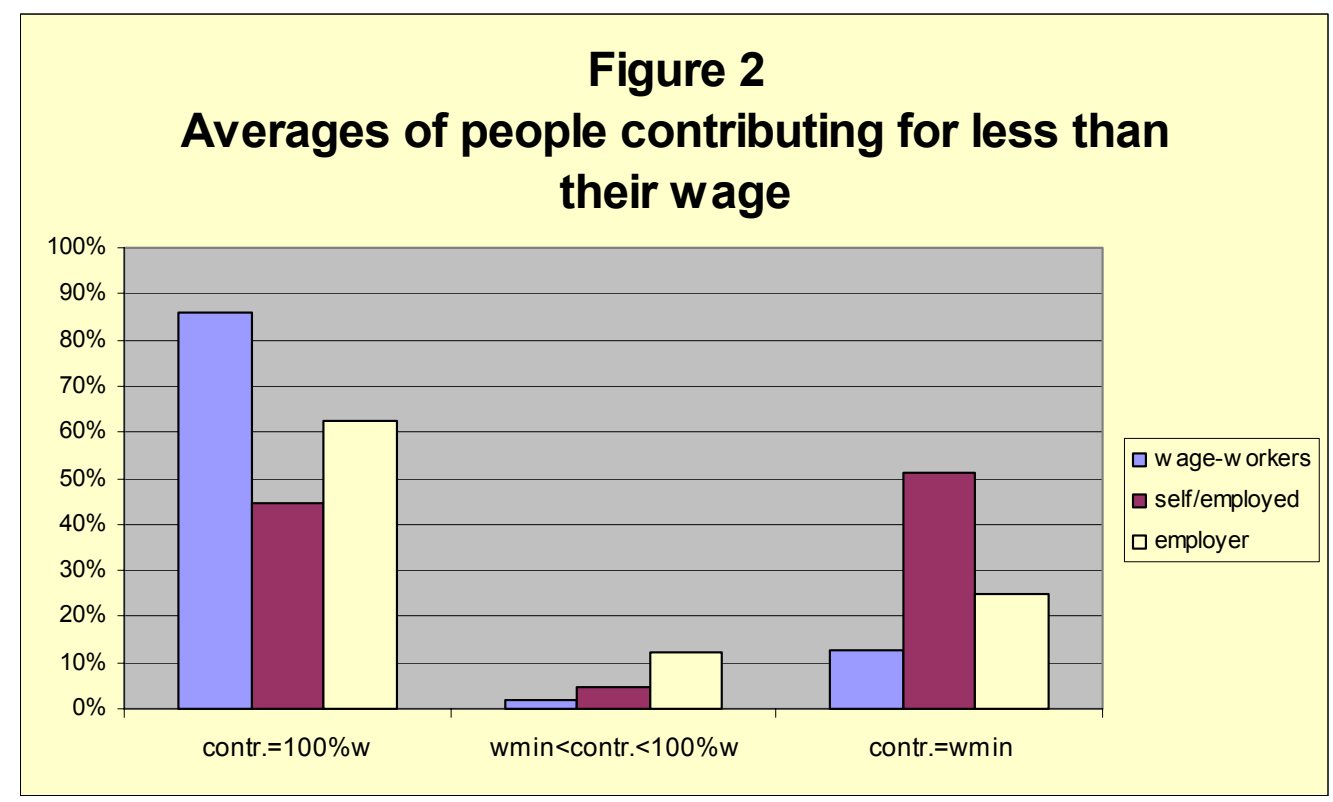

To complete the characterization of the density of contributions, Table 14 presents a set of multivariate regression with density of contributions as the dependent variable, based on the data in the Employment History and Social Security Survey. 
The alternative specifications start with a small set of variables and then sequentially add other groups of variables. First we consider the variables in the core group that are included in all specifications and then consider other variables that are added in other specifications.

\section{Core Variables:}

Gender: Specifications 1 to 3, which do not control for the employment pattern throughout the working life, show a higher density for men, as also is found in the bivariate associations in Table 7. However, the impact is reversed so that women have a higher density of contributions for the same employment experience in specifications 4 to 6 .

School attainment: Schooling has a positive but decreasing significant association with the density of contributions under all specifications in Table 14. The size of this association is cut to about two-fifths, however, once the labor market history is introducted in specification 4 . This is consistent with schooling affecting the density of contributions primarily through affecting labor market choices and outcomes regarding work category, employment and unionization.

Age: Age has a positive but decreasing significant association with the density of contributions under all specifications in Table 14. This is consistent with the findings in previous tables that the density of contributions increases with the age of the interviewees but at decreasing rates. The size of this association is cut to about a seventh, however, once the labor market history is introducted in specification 4. This suggests that important factors in increasing the density of contributions over the life cycle may include changes in employment rates and in types of employment.

Household head and marital status: Heads of households have higher density rates in specifications 1-3; nevertheless, this effect is not significant when the labor market experience of the interviewees is controlled (from specification 4). Marital status does not appear to have a significant association in the most of the the specifications, though being married has a positive coefficient estimate in the most extensive specification (7).

Disability: Having a disability reduces the density of coverage by about 11 or 12 percentage points in the simplest specifications. However, once again, this association becomes insignificant once there is control for labor market experience. 
Table 14

Regressions for the density of contributions

(Dependent Variable: $d=$ density of contributions)

\begin{tabular}{|c|c|c|c|c|c|c|c|c|}
\hline & Specific & tion 1 & Specific & tion 2 & Specific & ion 3 & Specif & tion 4 \\
\hline Variable & Coeff. & t-stat & Coeff. & t-stat & Coeff. & t-stat & Coeff. & t-stat \\
\hline Years of schooling & 0.02666 & $9.8^{*}$ & 0.02459 & $9.0^{*}$ & 0.02459 & $8.6^{*}$ & 0.00930 & $3.9^{*}$ \\
\hline Years of schooling squared & -0.00076 & $-5.8^{*}$ & -0.00072 & $-5.5^{*}$ & -0.00072 & $-6.4^{*}$ & -0.00024 & $-2.1^{*}$ \\
\hline Age & 0.03618 & $35.1^{*}$ & 0.03598 & $34.8^{*}$ & 0.03598 & $33.7^{*}$ & 0.00524 & $5.7^{*}$ \\
\hline Age squared & -0.00034 & $-33.1^{*}$ & -0.00034 & $-33.0^{*}$ & -0.00034 & $-31.6^{*}$ & -0.00003 & $-3.4^{*}$ \\
\hline Single=1 & 0.00578 & 0.8 & 0.00920 & 1.3 & 0.00920 & 1.5 & -0.00366 & -0.7 \\
\hline Head of Household=1 & 0.06913 & $9.7^{*}$ & 0.07066 & $10.0^{*}$ & 0.07066 & $9.6^{*}$ & 0.00627 & 1.2 \\
\hline Disability=1 & -0.12327 & $-11.2^{*}$ & -0.11830 & $-10.8^{*}$ & -0.11830 & $-9.3^{*}$ & -0.01498 & -1.6 \\
\hline Male=1 & 0.12995 & $20.9^{*}$ & 0.12305 & $18.7^{*}$ & 0.12305 & $18.4^{*}$ & -0.01201 & $-2.3^{*}$ \\
\hline Poverty in childhood=1 & & & -0.03322 & $-5.5^{\star}$ & -0.03322 & $-4.8^{*}$ & -0.02231 & $-4.8^{*}$ \\
\hline Progress $=1$ & & & 0.05083 & $8.8^{*}$ & 0.05083 & $7.7^{*}$ & 0.02596 & $5.9^{*}$ \\
\hline Military Service=1 & & & 0.02399 & $3.2^{*}$ & 0.02399 & $3.3^{*}$ & 0.01518 & $2.6^{*}$ \\
\hline Planning Horizon=1 & & & & & 0.03282 & $5.6^{*}$ & 0.00992 & $2.4^{*}$ \\
\hline Smoker=1 & & & & & -0.00348 & -0.6 & -0.01466 & $-3.6^{*}$ \\
\hline Bad Health=1 & & & & & -0.05010 & $-4.0^{*}$ & -0.00273 & -0.3 \\
\hline Labor Training=1 & & & & & 0.07480 & $12.6^{*}$ & 0.01781 & $4.3^{*}$ \\
\hline$\%$ as wage-worker & & & & & & & 0.11979 & $12.5^{\star}$ \\
\hline$\%$ as self/employed & & & & & & & -0.28494 & $-19.6^{*}$ \\
\hline$\%$ of time employed & & & & & & & 0.75075 & $91.3^{*}$ \\
\hline$\%$ of time unionized & & & & & & & 0.06237 & $12.1^{*}$ \\
\hline R2 & 0.199 & & 0.204 & & 0.215 & & 0.566 & \\
\hline n & 15871 & & 15871 & & 15799 & & 14831 & \\
\hline
\end{tabular}


Table 14

Regressions for the density of contributions

(Dependent Variable: $d=$ density of contributions)

\begin{tabular}{|c|c|c|c|c|c|c|}
\hline \multirow[b]{2}{*}{ Variable } & \multicolumn{2}{|c|}{ Specification 5} & \multicolumn{2}{|c|}{ Specification 6} & \multicolumn{2}{|c|}{ Specification 7} \\
\hline & Coeff. & t-stat & Coeff. & t-stat & Coeff. & t-stat \\
\hline Years of schooling & 0.00930 & $2.4^{*}$ & 0.00916 & $2.4^{*}$ & 0.01285 & $3.7^{*}$ \\
\hline Years of schooling squared & -0.00022 & $-2.0^{*}$ & -0.00021 & $-1.9^{\star *}$ & -0.00039 & $-2.6^{*}$ \\
\hline Age & 0.00513 & $5.6^{*}$ & 0.00513 & $5.6^{*}$ & 0.00309 & $2.3^{*}$ \\
\hline Age squared & -0.00003 & $-3.3^{*}$ & -0.00003 & $-3.3^{*}$ & 0.00000 & -0.6 \\
\hline Single=1 & -0.00351 & -0.7 & -0.00341 & -0.7 & -0.01049 & $-2.0^{*}$ \\
\hline Head of Household=1 & 0.00596 & 1.2 & 0.00596 & 1.2 & 0.00582 & 1.1 \\
\hline Disability=1 & -0.01492 & -1.6 & -0.01500 & -1.6 & 0.00197 & 0.2 \\
\hline Male $=1$ & -0.01239 & $-2.4^{*}$ & -0.01226 & $-2.3^{*}$ & -0.00401 & -0.7 \\
\hline Poverty in childhood=1 & -0.02116 & $-4.6^{*}$ & -0.02125 & $-4.6^{*}$ & -0.01575 & $-3.2^{*}$ \\
\hline Progress=1 & 0.02601 & $5.9^{*}$ & 0.02613 & $6.0^{*}$ & 0.01625 & $3.7^{*}$ \\
\hline Military Service=1 & 0.01454 & $2.5^{\star}$ & 0.01453 & $2.5^{*}$ & 0.00802 & 1.3 \\
\hline Planning Horizon=1 & 0.00914 & $2.2^{*}$ & 0.00927 & $2.2^{*}$ & 0.00481 & 1.1 \\
\hline Smoker=1 & -0.01404 & $-3.4^{*}$ & -0.01401 & $-3.4^{*}$ & -0.00661 & -1.6 \\
\hline Bad Health=1 & -0.00326 & -0.3 & -0.00338 & -0.3 & -0.00594 & -0.5 \\
\hline Labor Training=1 & 0.01784 & $4.3^{*}$ & 0.01788 & $4.3^{*}$ & 0.01044 & $2.5^{*}$ \\
\hline$\%$ as wage-worker & 0.11946 & $12.5^{*}$ & 0.11895 & $12.5^{*}$ & 0.11128 & $9.3^{*}$ \\
\hline$\%$ as self-employed & -0.28476 & $-19.6^{*}$ & -0.28526 & $-19.7^{*}$ & -0.32721 & $-16.9^{*}$ \\
\hline$\%$ of time employed & 0.75250 & $91.6^{*}$ & 0.75281 & $91.6^{*}$ & 0.78292 & $85.4^{*}$ \\
\hline$\%$ of time unionized & 0.06293 & $12.0^{*}$ & 0.06281 & $12.0^{*}$ & 0.05508 & $9.9^{*}$ \\
\hline Regional Dummies & Yes & & Yes & & Yes & \\
\hline Per-cap.Total Household Income & & & -0.00000 & -0.6 & -0.00000 & -0.8 \\
\hline Repeated at school=1 & & & & & -0.01348 & $-3.1^{*}$ \\
\hline Knowledge of s.sec.contrib.=1 & & & & & 0.01216 & $2.8^{*}$ \\
\hline Knowledge of s.sec.charges $=1$ & & & & & 0.01889 & $2.5^{\star}$ \\
\hline Risk averse $=1$ & & & & & 0.00876 & $1.9^{* *}$ \\
\hline Propensity to consume $=1$ & & & & & -0.02728 & $-4.7^{*}$ \\
\hline R2 & 0.567 & & 0.567 & & 0.644 & \\
\hline n & 14831 & & 14831 & & 10643 & \\
\hline
\end{tabular}

Notes:

-All specifications include a constant term.

-Method is Ordinary Least Squares with corrections for heteroskedasticity.

${ }^{*}$ Coefficient is significant at $5 \%$; ${ }^{* *}$ Coefficient is significant at $10 \%$ 
Selected variables that are added in other specifications:

Poverty in childhood: Reported poverty in childhood is associated with a reduction of 0.02-0.03 in the density of contributions. This association holds even when labor market experience is controlled. This variable could be capturing unobserved human capital or other unobserved individual characteristics that affect the density of contributions.

Intergenerational progress: A dichotomous variable that indicates whether the individual currently has a better or much better socio-economic situation than that of the home in which he/she grew up is significant in every case (Progress $=1$ ): thus, individuals that have progressed economically since their childhood have a higher propensity to make social security contributions (this effect holds even when employment experience is controlled).

Military service: Having had military service is associated with a significantly higher ( 0.02 to 0.03 ) density of contributions in all the specifications except the seventh one. This is consistent with those in the military learning about and developing habits of participating in various formal institutions.

Longer planning horizon: Individuals with a longer time horizon for planning their savings and family expenses have a higher density of contributions for virtually all specifications (the variable "Planning Horizon $=1$ " has value of 1 if individuals consider one year or more as the horizon for planning their savings and family expenses and 0 if the horizon is less).

Smoker: In a number, but not all, of the specifications, smoking is associated negatively with the density of contributions. This inverse association is consistent with smokers having lower discount rates or with smokers having shorter life expectancies, both of which might lower the density of contributions.

Bad health: Bad health is negatively associated with the density of contributions in specification 3, which again may be associated with expectations of less to be gained from the pension system due to shorter life expectancy. But this association no longer is significant once labor market experience is included.

Labor training: Those with at least one labor training course since 1980 had a higher density. This is consistent with a positive relationship between human capital investment and the density of contributions. This association also weakens substantially with control for labor market experience.

Labor market experience: As noted, a number of the associations of the core variables with the density of contributions weak or disappear once there is control for labor market experience. The greater the proportion of time worked as a wage worker and the less time worked as an independent, the greater is the density of contributions. The density also increases substantially with higher employment rates of the interviewees in the last 20 years (variable \% of time employed).

Having repeated grade in school: Having repeated a school year is negatively associated with the density of contributions. This variable may be capturing lower abilities, controlling for schooling attainment. 
Knowledge of social security system: Knowledge of some basic aspects of the Chilean social security system is associated with higher densities of contributions. Two dichotomous variables have been built: one takes 1 as its value if the affiliates know the percentage of the contribution to the pension system and 0 if not; and the other takes the value of 1 if the affiliates know the commissions charged for the administration of their pension funds in the AFP system and 0 if they do not.

Risk aversion: Social security savings also increase with risk aversion, as might be expected. A dichotomous variable with the value of 1 is used as a measure of risk aversion, in this case for individuals who prefer a job that guarantees a fixed and sure life-long income in comparison with another that may pay better but with a less certain income.

Propensity to consume: The variable "Propensity to consume $=1$ " has a value of 1 for affiliates that would dedicate that amount to consumption expenses, if they were not obliged to contribute; and 0 if they would to dedicate that amount to other types of savings and investment. The results show that a higher propensity to consume is correlated with lower densities of contribution. 


\subsection{Replacement rates and the density of contributions}

This section examines the impact of the density of contribution on income replacement rates. The analysis uses the following basic assumptions:

- Initial Taxable Income: $\$ 200,000$ (somewhat below twice the current minimum wage);

- Real salary grows $2 \%$ per year until 50 years of age;

- Pension fund return rates: $4 \%$ real annual;

- Fixed monthly commission: $\$ 500$;

Figures 3 and 4 show the results of different scenarios in terms of accumulated capital at the moment of withdrawal and replacement rates. The following scenarios are analyzed:

a) Male who gets pension at 65 years of age with female partner 5 years younger; density of contributions: $80 \%$;

b) Male who gets pension at 65 years of age with female partner 5 years younger; density of contributions: $60 \%$;

c) Female who gets pension at 60 years of age; density of contributions: $80 \%$;

d) Female who gets pension at 60 years of age; density of contributions: $43 \%$;

Figure 3 contains the results of social security savings up to 65 years of age (for men) and up to 60 years of age (for women). Figure 4, indicates the respective replacement rates for these cases (defined as the percentage of the last remunerations covered by the monthly pension).

A man with a pension at 65 and with a density of $80 \%$ accumulates a capital of $\$ 37$ million, which finances a pension that reaches nearly $60 \%$ of his pre-retirement remuneration. For men, this accumulated amount must also finance a survivor's pension for their spouses and dependant children.

The same density assumption applied to a female affiliate reflects that she has a lower retirement age. Thus, the accumulated savings, with the same assumptions of remuneration, rates of return and density of contributions, would reach $\$ 29$ million. Considering these low savings, apart from the higher life expectancy of women, women have to finance a pension for longer and with less. This is partly made up by the fact that women do not leave a survivor pension. In this scenario, women have a replacement rate of $43 \%$.

However, the previous exercises assume an average density of $80 \%$. As indicated above, these are the usual assumptions used in pension projections in Chile from the outset of the system.

The impact of lower average densities is detrimental, as is observed in figures 3 and 4. When using the effective densities of contributions of affiliates (60\% for men and $43 \%$ for women), the accumulated capital decreases between $25 \%$ and $46 \%$ with comparison to the scenario in which densities of $80 \%$ are assumed. In fact, the projected pensions decrease from $58 \%$ of the last salary (with $80 \%$ density) to $44 \%$, for men, and from $43 \%$ to $23 \%$ in the case of women. 
In conclusion, it is essential to consider the effective contribution histories of the affiliates of the AFP system because they affect importantly the pension amounts at the end of the working life. This issue has been unexplored to date in the debate on the Chilean pension system. It is clear that densities of contributions below those used in the minimum pension projections would imply an increase in the projected public expenditure for the next few years for this item.

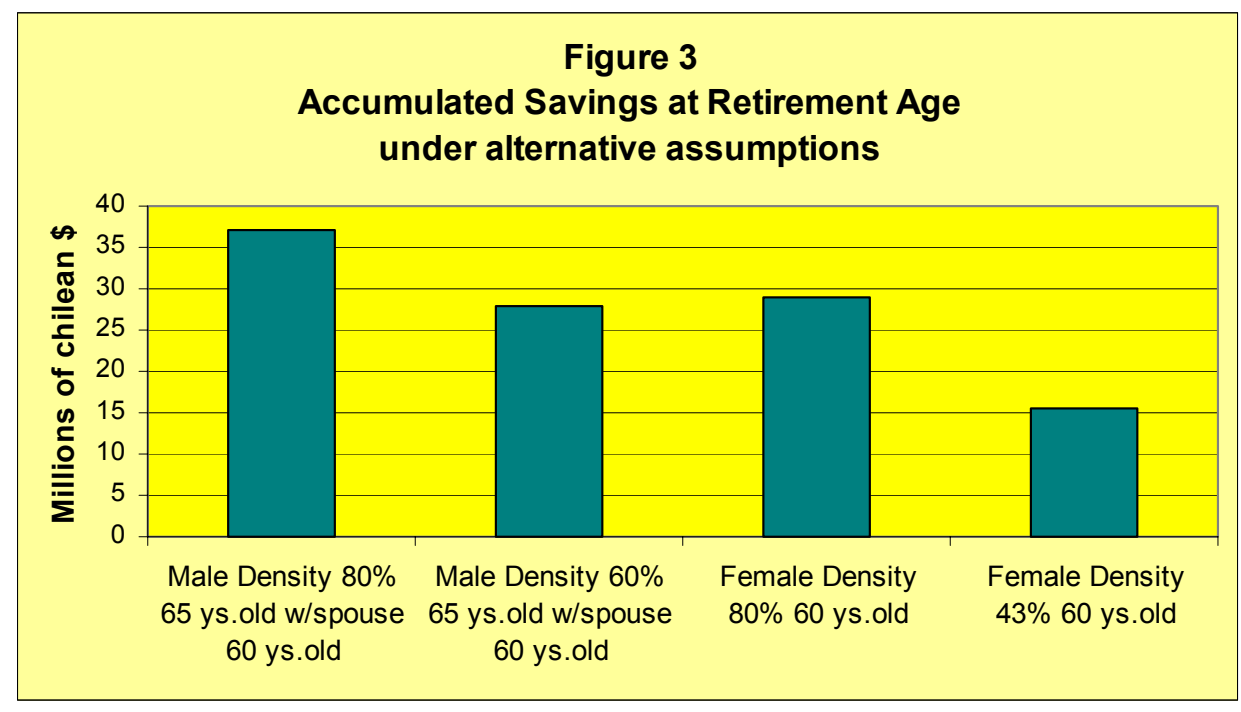




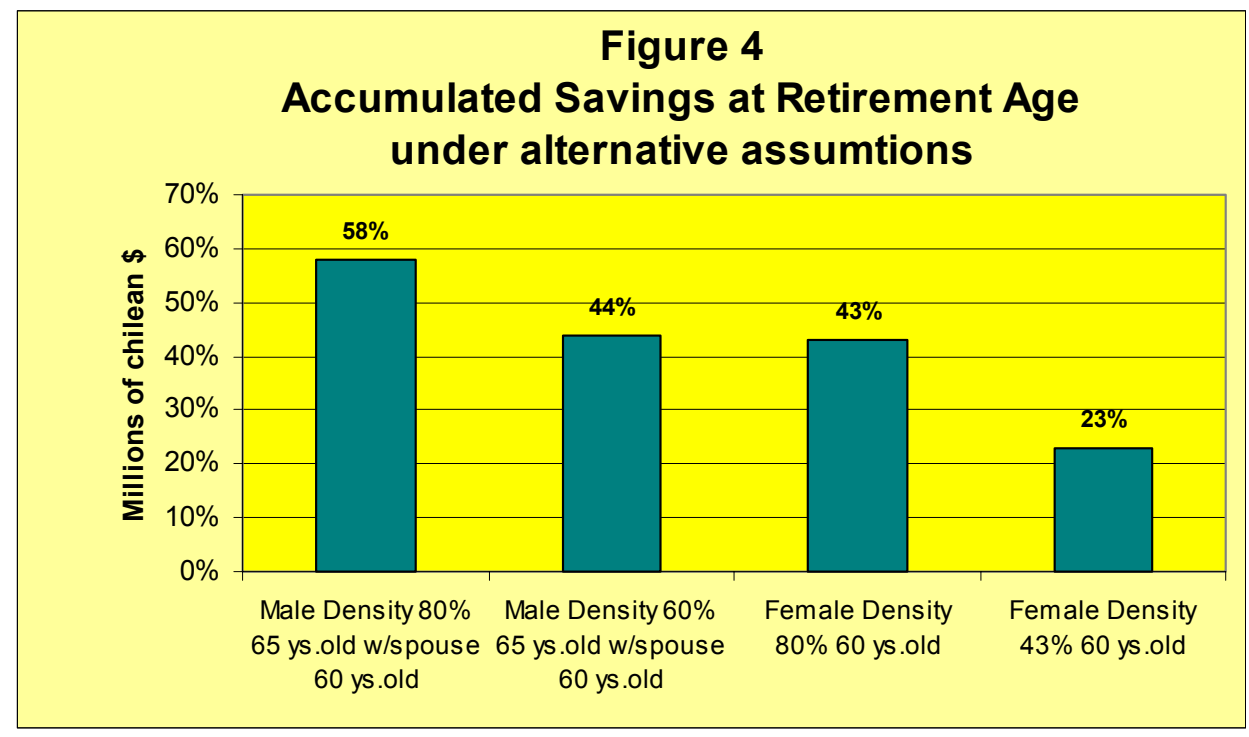




\section{Conclusions and policy implications}

The purpose of social security is to guarantee citizens access to benefits that can provide them with income stability in their post-retirement years, in the case of individuals who can generate these savings by themselves, and a minimum subsistence level for those who cannot accumulate those savings on their own. Higher or lower social security coverage affects the capacity of workers to finance their own pensions once retired or to be adequately covered in case of accidents. Low social security coverage leads to more workers receiving only the minimum statutory pensions or social assistance pensions. Similarly, a low coverage implies a lower average value of the benefits pensioners can obtain.

With regard to these considerations, it should be noted that the coverage of the pension system is closely tied to the limitations and restrictions of the labor market. The latter is constantly evolving, and is influenced by the natural changes of the economy and by policies. To the extent that these labor market changes increase or reduce the precariousness of labor relations and the incentives that workers, especially independent and low-income workers, have to participate in the pension system, there will be a direct effect on labor social security coverage. Therefore, labor social security coverage is an issue that should not be restricted to the sphere of social security or social policies, since, given the nature of the factors involved, it is in fact affected by virtually all public policies, especially those dealing with the labor market. Thus, the need arises for an integrated policy framework that may improve labor social security coverage, and avoid, on the one hand, negative effects ion the coverage and amounts of the social security benefits of the passive $=$ or, and on the other hand, the fiscal risks associated with a low level of covera

Measures focused at improving benefits, such as improvements in the levels of contributory and assistance pensions, and coverage extension, should be evaluated taking their short and long-term effects into account. Excessively generous benefits, in terms of amounts and requirements, increase the risk of definancing, not only because of the need to cover higher benefit payments, but also because loosening the conditions on providing benefits promotes the evasion of social security contributions, including pension contributions.

Implementing policies to increase pension coverage is one of the pending challenges of the Chilean pension system. The characterization of the non-affiliated population that does not make contributions to the social security system is key to be able to design good policies and to target and reach the potential beneficiary population, a point that has been looked at in detail in this study.

Furthermore, this study shows that it is also necessary to look at the density of contributions of affiliated and contributing workers in the pension system.

In fact, it is common to find assumptions on the density of contribution ranging between $80 \%$ and $100 \%$ in the social security deficit estimates or in the calculations of pension amounts in the AFP system. However, the latest statistics, assembled from self-reporting by affiliates in the HLSS Survey, show average densities of around $50 \%$. What is the impact of this lower density of contributions? The simulation exercises presented in this study indicate that the actual density of effective contributions of the various groups implies substantially lower replacement rates (below $25 \%$ ) than assumptions of an $80 \%$ density rate. Of course, this 
phenomenon presents serious repercussions on the amounts to be received by future pensioners and on fiscal consequences in terms of the outlay on minimum and assistance pensions.

It should be noted that these exercises have been carried out supposing a real annual return rate of $4 \%$. Given that the Chilean system has averaged real annual return rates of over $10 \%$ since 1981 , if such rates should exist in the future, higher pensions could be funded. However, recent pension fund return rates show that it is imprudent to use higher rates for future projections.

In this context, improving coverage, for low income wage as well as independent workers, looking for adequate social security deficit financing mechanisms, especially during the social security transition, promoting actuarial and financial studies, as well as creating mechanisms that allow the affiliate to not only have adequate information on the administration of their pension funds, but also to have the tools to make the best use of that information, are part of the pending tasks of the AFP pension system.

One may gather from the above analysis that increasing the coverage of the Chilean pension system is a priority and requires specific policies. One of the most important challenges is certainly to increase the coverage for low-income workers as well as for women and independent workers.

Improving the information that the insured have with regard to the pension system should be one of the most relevant concerns in the future. Informed decisions by affiliates requires an understanding of both the functioning of the system in general, as well as of the requirements and benefits of the various pension modalities available upon retirement.

There is a widespread agreement that the information level on the private pension programs is minimal. This is demonstrated in the results of the HLSS Survey (see Bravo, 2004). As such, educational programs should be implemented, through unions and the mass media. This could also help the insured to decide among the pension options when retiring, and to further reduce the levels of migration among AFPs. A new social security culture must be developed as a priority in the areas of information and education. it is essential to program and develop mass education modules that allow workers to fully see the benefits and obligations that the individual capitalization system offers, which could also be incorporated into the school curriculum in secondary level schools.

Additionally, it cannot be assumed that because policy makers tend to ignore gender distinctions, the policies they design are operationally neutral. Indeed, gender issues have not been dealt with in depth on a government, academic or political level in the pension system reform processes (Arenas de Mesa and Montecinos, 1999).

The gender equality issue in social security has been targeted in developed countries in the last few years. Issues such as the differences in retirement age, credit in years of contributions for women who take care of children and elderly people, coverage for housewives, part-time workers, domestic help workers or in seasonal activities such as agriculture and the retail sector have been discussed and reforms have been incorporated to improve gender equity in social security in the 1990s (ILO 1993).

In contrast, the gender dimension in Latin America as a whole has been ignored or studied insufficiently, even though the issue of social security and women has 
become increasingly important due to the increasing labor market participation of women, to their increasing participation in the pension market as primary beneficiaries; and to the fact that numerous social security systems have been and are being reformed and to ongoing demographic changes. Though interest is increasing in the topic, many questions still remain unanswered. Studying the pension system from a gender perspective is a challenge for the future, identifying how the employment behavior of men and women affects the pensions of these groups, as well as identifying and overcoming possible system design problems that could negatively affect women's pensions.

The gender issue should not be sidelined, especially considering that the projected increase in the number and relative importance of the female labor force will shape, among other factors, the future evolution of the labor and pension markets.

Measures aimed at risk-sharing, be it through the elimination of gender differences in retirement age and mortality tables, or through the creation of family accounts, could be an incentive to increase female participation in the system and so reduce the possibilities of low pension levels and increasing fiscal subsidies.

Furthermore, the level of understanding that women have of the system should be known as well as the negative effect of women retiring at 60 years of age (five years before men) on the pension amounts, to propose information policies that allow and promote setting back the retirement age past the current level of 60 .

Since 1981, the State has had to cover the social security deficit created by the new pension system, which is currently slightly under $5 \%$ of GDP. This puts considerable pressure on the fiscal coffers, which should be dropping over time, as the relative importance of the transitory commitments of the State with the social security system, the operational deficit and the recognition bonds, is reduced and the permanent components increase, the minimum state and assistance pension guarantee.

From this perspective, social security coverage is not neutral, in that it has an influence in the accumulation of resources by affiliates in the new social security system, and thus, in the need to finance, with State resources, minimum or assistance pensions. Consequently, a good fiscal practice is to push towards measures that improve social security coverage, thus reducing future pressures on the State.

As regards low-income workers, employment and formalization policies should play the key role, avoiding opportunist behavior that reduces social security savings. The supervision of social security contributions should be strengthened within an institutional framework that ensures effect recovery of the contributions through a rational and efficient use of sanctions (fines and others). 


\section{References}

Arellano, José Pablo. 1985. Políticas sociales y desarrollo. Chile 1924-1984. Santiago, CIEPLAN.

Arenas de Mesa, Alberto. 1999. "Proyecciones del déficit previsional chileno : Gasto público en pensiones asistenciales 1999-2010." XI Seminario Regional de Política Fiscal, CEPAL, Brasilia, January 26-28.

---, 1997. "Learning from the privatization of the social security pension system in Chile: Macroeconomic Effects, Lessons and Challenges." Ph.D. diss. University of Pittsburgh. Pittsburgh.

Arenas de Mesa, Alberto and Verónica Montecinos. 1999 "The Privatization of Social Security and Women's Welfare: Gender Effects of the Chilean Reform." Latin American Research Review, Vol 34. No 3 (forthcoming).

Arenas de Mesa, Alberto and Fabio Bertranou. 1997. "Learning from Social Security Reforms: Two Different Cases, Chile and Argentina." World Development, Vol. 25, No. 3 (March).

Arenas de Mesa, Alberto and Mario Marcel C. 1993. "Proyecciones de gasto previsional 1992 -2038: Un modelo de simulación para los bonos de reconocimiento." Santiago: Dirección de Presupuestos, Ministerio de Hacienda, Documento de Trabajo (February).

Arrau, Patricio. 1991. "La reforma previsional chilena y su financiamiento durante la transición" Santiago: CIEPLAN, Colección Estudios, Vol. 32, (June): 5-44.

Baeza, Sergio and Francisco Margozzini, eds. 1995. Quince años después. Una mirada al sistema privado de pensiones. Santiago: CEP.

Bravo, D. (2004), "Evaluación de los resultados del sistema de pensiones. Informe Final". January. Departamento de Economía, Universidad de Chile.

Cheyre, Hernán. 1988. La previsión en Chile ayer y hoy. Santiago: CEP.

Diamond, Peter. 1994. "Privatization of Social Security: Lessons from Chile." Revista de Análisis Económico, Vol. 9, No. 1, (June): 21-33. Santiago: ILADES.

Diamond, Peter and Salvador Vadés-Prieto. 1994. "Social Security Reform." In B. Bosworth, R. Dornbusch and R. Labán, eds., The Chilean Economy. Chapter 7: 257328. Washington D.C.: The Brookings Institution.

Feldstein, Martin 1996. "The Missing Piece in Policy Analysis: Social Security Reform." NBER Working Paper, No 5281, (January). Cambridge, MA: National Bureau of Economic Research.

Heller, P.S. (1998), "Rethinking Public Pension Reform Initiatives", IMF Working Papers 98/61, April. 
Hernández, Héctor and Alberto Arenas de Mesa. 1999. "Proyecciones del déficit previsional chileno: Gasto en garantía estatal de pensiones mínimas 1999-2037." Documento interno de trabajo, Dirección de Presupuestos, Ministerio de Hacienda. (Manuscript).

Holzmann, Robert. 1994. "Funded and Private Pensions for Eastern European Countries in Transition." Revista de Análisis Económico, Vol. 9, No 1, (June): 169210. Santiago: ILADES.

-----------. 1996. "Pension reform, financial market development and economic growth : preliminary evidence from Chile." WP/96/94 (August). Washington. D.C. : IMF.

Iglesias, Augusto and Rodrigo Acuña. 1991. Chile: Experiencia con un régimen de capitalización 1981-1991. Santiago: CEPAL/PNUD.

Kotlikoff, Laurence.1996. "Simulating the Privatization of Social Security in General Equilibrium." NBER Working Paper, No. 5776 (September). Cambridge, MA: National Bureau of Economic Research.

Marcel, Mario and Alberto Arenas. 1992. "Social Security Reform in Chile." InterAmerican Development Bank (IDB), Occasional Papers, No 5. Washington, D.C.: IDB.

Margozzini, Francisco. 1988. "Estimaciones de las pensiones de vejez que otorgará el actual sistema de pensiones." In S. Baeza and R. Manubens, eds., Sistema privado de pensiones en Chile.: 251-274. Santiago: CEP.

Mesa-Lago, Carmelo. 1994. Changing Social Security in Latin America: Toward Alleviating the Costs of Economic Reform. Boulder and London: Lynne Rienner Publishers, Inc.

-------. 1996. "Las reformas de pensiones de seguridad social en América Latina: Sistemas públicos, privados, mixtos y paralelos." Estudios de la Seguridad Social, No. 80: 58-85.

Mesa-Lago, Carmelo and Alberto Arenas de Mesa. 1999. "Fifteen years after the privatization of the Chilean Pension System: Evaluation, Lessons and Challenges." In Reforming Pension and Health Care System in Latin America: What are the options? edited by Maria Amparo Cruz-Saco and Carmelo Mesa-Lago. University of Pittsburgh Press. Pittsburgh (march).

Ortúzar, Pablo. 1988. "El déficit previsional : recuento y proyecciones." In Baeza, Sergio and Rodrigo Manubens, Sistema privado de pensiones en Chile. Santiago: CEP.

Paredes, Ricardo, Pilar Romaguera, and Andras Uthoff. 1987. "Modelos de capital humano y segmentación: Test y nueva evidencia." Estudios de Economía. Vol. 14, No 2 (December): 335-372. Santiago: Universidad de Chile.

Pini, Claudio Javier. 1998. "El déficit operacional del sistema público de pensiones en Chile: Análisis, proyecciones e implicancias de política." Preliminary Draft, diss. Master degree. ILADES-Georgetown University. (manuscript, December). 
Superintendencia de Administradoras de Fondos de Jubilaciones y Pensiones (SAFJP), Superintendencia de Administradoras de Fondos de Pensiones (SAFP), and Superintendencia de Administradoras Privadas de Pensiones (SAPFP). 1996. Reformas a los sistemas de pensiones. Argentina, Chile, Perú. Santiago: SAFJP, SAFP, SAPFP.

Superintendencia de Administradoras de Fondos de Pensiones (SAFP). 1996. El sistema chileno de pensiones. Santiago: SAFP (third edition).

Wagner, Gert. 1991. "La seguridad social y el programa de pensión mínima garantizada." Estudios de Economía, Vol. 18, No. 1 (June): 35-91. Santiago: Universidad Católica de Chile.

Zurita, Salvador. 1994. "Minimum pension insurance in the Chilean pension system." Revista de Análisis Económico, Vol 9. № 1. (June): 105-126. Santiago: ILADES. 